
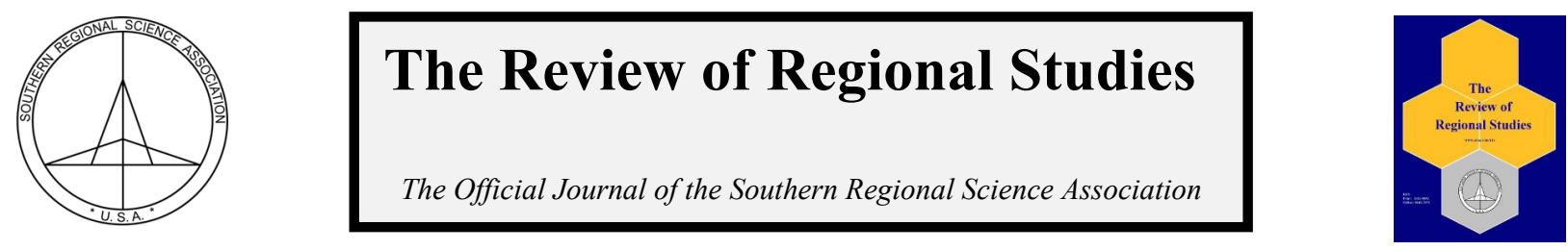

\title{
A Multiregional Dynamic CGE Model of Growth Oriented State Tax Reforms: An Application to Georgia and Five Comparison States*
}

\author{
Jeffrey Condon ${ }^{\mathrm{a}}$, Andrew Feltenstein ${ }^{\mathrm{a}}$, Florenz Plassmann ${ }^{\mathrm{b}}$, Mark Rider ${ }^{\mathrm{a}}$ and David L. Sjoquist ${ }^{\mathrm{a}}$ \\ ${ }^{a}$ Department of Economics, Georgia State University, USA \\ ${ }^{b}$ Department of Economics, Binghamton University, USA
}

\begin{abstract}
A number of U.S. states are considering tax reforms that would significantly reduce or eliminate income taxes and recover the lost revenue by increasing its sales taxes. To gauge the economic effects of such reforms, we construct a multi-regional, dynamic, open economy, general equilibrium (CGE) model. Our model is an advancement over existing regional CGE models used to simulate the impact of state tax reforms in the U.S. context. We simulate the impact of a variety of tax reforms and find that Georgia's economy benefits but at the expense of the five comparison states we include.
\end{abstract}

Keywords: dynamic simulation models, fundamental tax reform

JEL Codes: $\mathrm{H} 71$

\section{INTRODUCTION}

Fundamental national tax reform in the United States, by which is meant substituting a broad-based consumption tax for the existing federal income tax, has been an important topic of ongoing policy discussion and of research for the past several decades. ${ }^{1}$ A growing number of American states are now discussing the merits of legislative proposals to change their tax structures by significantly decreasing the proportion of tax revenue raised through the income tax and are replacing the lost revenue with an expanded sales tax base and/or increased sales tax rate. The principal economic argument for doing so is to reduce the distortionary tax on capital income, thereby promoting increased capital accumulation which, in turn, increases the state's long-run economic growth rate. While there are several studies that explore the effects of fundamental national tax reform for the United States' economy, we find no research addressing

\footnotetext{
*The authors thank the editor and three referees for their helpful comments and suggestions, and gratefully acknowledge the financial support provided by the Fiscal Research Center at Georgia State University.

Jeffrey Condon received his Ph.D. in Economics from Georgia State University. Andrew Feltenstein is Professor of Economics at Georgia State University. Florenz Plassman is Professor of Economics and Department Chair at Binghamton University. Mark Rider is Associate Professor of Economics at Georgia State University. David Sjoquist is Professor of Economics, holder of the Dan E. Sweat Distinguished Scholar Chair in Educational and Community Policy at Georgia State University. Corresponding Author: D. Sjoquist, Email: sjoquist@gsu.edu

${ }^{1}$ Several specific proposals for substituting a consumption tax for personal and corporate income taxes by the federal government have been advanced; examples include the X Tax (Bradford 2003), the Fair Tax (Boortz and Linder 2005; 2008), and the Flat Tax (Hall and Rabushka 2007). Pechman (1980), Aaron and Gale (1996) and Diamond and Zodrow (2008) are examples of recent studies of the effect of fundamental tax reform at the national level.
}

(C) Southern Regional Science Association 2015.

ISSN 1553-0892, 0048-749X (online)

www.srsa.org/rrs 
this issue at the state level for the U.S. case. This is so despite the policy interest in such statelevel reforms. ${ }^{2}$ The purpose of this study is to address this gap in the literature.

At the time of this writing, no U.S. state has fully repealed its income tax and replaced it with an expanded role for the sales tax. Nevertheless, proposals to reduce or to eliminate the state income tax and replace the lost revenue with sales tax reform are being considered in a dozen states, namely Georgia, Hawaii, Idaho, Kansas, Louisiana, Missouri, Nebraska, New Jersey, Ohio, Oklahoma, Oregon and South Carolina. Bourdeaux (2010) reports that state tax reform commissions in Oklahoma and Oregon recommended eliminating their state income taxes. Georgia's 2010 tax reform commission proposed a broadening of the sales tax base to include services and a substantial reduction in the state personal income tax (PIT) to make the reform revenue neutral. Hawaii's 2005-2007 tax review commission recommended investigating the elimination of the state income tax. A recent tax reform commission in Louisiana proposed replacing the income tax with an increase in the sales tax rate. According to Hamilton (2012), the governors of four states (Idaho, Nebraska, New Jersey and Ohio) proposed major one-time cuts in state PIT rates; Kansas recently enacted a significant reduction in its income tax; and serious consideration is being given to phasing out the PIT in two states (Missouri and Oklahoma).

Given the number of U.S. states considering such proposals, an analysis of their effects on economic growth and welfare would clearly add to our understanding of this important policy debate. To that end, we construct a multiregional, dynamic, open economy, general equilibrium model to gauge the effect of three tax reform options on economic growth and welfare in the reform state. This model builds on the work of Plassmann (2005) and Feltenstein and Plassmann (2008). Previous studies using simulation models to gauge the effect of state tax reforms in the United States generally employ static models with two regions, the state and the rest of the world. There are several examples of quite sophisticated regional computable general equilibrium (CGE) models that have been used to simulate subnational fiscal reforms, particularly for the Australian and German contexts. ${ }^{3}$ Nonetheless, the model described below is an advancement over regional CGE models that have been used to simulate the impact of state fiscal reforms in the U.S. context, particularly fundamental state tax reform.

First, ours is a dynamic model. State tax reforms that reduce distortionary taxes on capital income will affect savings and investment behavior. Savings behavior therefore needs to be endogenously determined as part of intertemporal optimization, leading to the need for a dynamic model. Second, a multiregional model has several advantages over a two region model in the U.S. context. A multiregional model provides for differential responses by each of the comparison states and the rest of the United States (ROUS). These responses depend on the particular circumstances of each region in the model, particularly their tax and economic structures, relative to that of Georgia. The aggregate of these differential responses in a multiregional model, such as ours, may differ from the aggregate response of the rest of the world in a two region model. In the latter, the distinguishing features of individual regions are

\footnotetext{
${ }^{2}$ For example, see Diamond and Zodrow (2008) and the citations therein for a review of the literature on the effect of fundamental national tax reform on economic activity and welfare. There is a large literature on the economic effects of state and local taxes; however, research in this area generally focuses on the effect of interstate differences in state income taxes on economic growth, on interstate migration, on business location decisions, and on the effect of state sales tax rates differentials on cross-border shopping. See Rider (2006) for a review of this literature.

${ }^{3}$ See, for example, Hirte (1998) and Giesecke (2003). In addition, Giesecke and Madden (2013) provide a recent review of developments in regional CGE models.
}

(C) Southern Regional Science Association 2015. 
averaged out by aggregation. In addition, a multiregional model provides detailed information on the impact of Georgia's tax reform on each of the comparison states and the ROUS, which may be of independent interest, particularly to policymakers.

Finally, the feature that most distinguishes our model from that of others is the way in which we model interstate trade. We use a non-Armington approach in which goods traded between states are viewed as being identical and thus perfect substitutes in production and consumption. This approach has a number of advantages in a multiregional model of a highly integrated common market, like that of the U.S. Briefly, the typical Armington version of a multiregional economy would have a single type of labor in each region. Hence there would be a single wage rate for all sectors in a region, which would force us to neglect the relative wage effects of alternative fiscal policies. Since the reform options analyzed here involve partial and complete repeal of Georgia's PIT, which includes a tax on labor income, we believe that it is particularly important to account for the relative wage effects of such reforms. ${ }^{4}$

It is possible in an Armington context to have sector- and region-specific labor categories and hence, wages. But such a model expansion has significant costs in terms of increased data requirements, as well as computational complexity. A useful feature of our model, as detailed in Appendix A, is that sectoral wage rates in each region are derived from a "backwards solution" in which output prices are determined nationally and are taken as given by the individual states in our model. Capital is assumed to be perfectly mobile; so sectoral value added in each region is determined from the national prices of the sectors' outputs, as well as the intermediate costs derived from the regions' input-output matrices. Once a sector's nominal value added has been determined, and the price of capital is determined at the national level, the sector's wage rate (price of labor) is determined as a residual. Thus, there are eleven sectors in each of the six states' input-output matrices, as well as in the national matrix, in the model described below. If we were to incorporate sector specific labor, then we would have $7 \times 11$ wage rates to solve for in each period, along with the price of capital, or 78 dimensions per time period. A dynamic model for ten periods would require us to solve for 780 price dimensions, which would be quite a large task. Our approach requires solving for only the price of capital plus the eleven national wage rates or twelve total price dimensions in each period. Hence, for a ten-period model, we solve for 120 rather than 780 factor prices. ${ }^{5}$

Of course we do not claim that this approach is suitable for all trade models, just as we would not assert that the non-Armington approach described here is always appropriate. If there are data that indicate traded goods are not close substitutes or if we are dealing with a static rather than a dynamic model, which makes dimensionality a non-issue, then incorporating sectorspecific labor in an Armington context may well be a better approach. Finally, depending upon the circumstances, one may decide that it is worth solving a very large model. All things being equal, we believe that a smaller model is better than a very large one for our set of simulations.

In light of the diversity of reform proposals being considered by various American states, we simulate three tax reform options, assuming in each case that the reform is adopted by the state of Georgia. We simulate the effects of these reforms on Georgia's economy as well as their

\footnotetext{
${ }^{4}$ The first paper to use this non-Armington approach, Feltenstein (1997), was applied to a case in Australia in which a single state, Western Australia, was subject to an export tax on gold. The state traded perfectly substitutable intermediate and final goods with the other Australian states, and the non-Armington approach was used to derive differential wage rates for the different states.

${ }^{5}$ This approach is described in Appendix A.
}

(C) Southern Regional Science Association 2015. 
effects on five comparison states, namely Alabama, Florida, North Carolina, South Carolina, and Tennessee, and the ROUS. In Tax Reform Option A, we simulate the effect of expanding the sales tax base to include services and a revenue neutral reduction in the PIT rate. This is the reform option proposed in Georgia and several other states. Next, we simulate Tax Reform Option B which involves eliminating the state PIT altogether and a revenue neutral increase in the sales tax rate on the expanded sales tax base. Finally, in Tax Reform Option C, or what may be referred to as fundamental state tax reform, we simulate the effect of eliminating the state income tax, that is both the state PIT and corporate income tax (CIT), and a revenue neutral increase in the sales tax rate on the expanded sales tax base. In this manner, we are able to address the benefits of incremental tax reforms where the last incremental reform results in fundamental state tax reform.

According to the simulations, these reforms have positive effects on Georgia's economy relative to a pre-reform baseline; however, these benefits come at the expense of reduced economic growth in each of the five comparison states as well as the ROUS. By increasing the after-tax rate of returns to capital in Georgia relative to that in the other states, the reform options allow Georgia to attract capital from the comparison states and the ROUS. This increase in capital per worker, in turn, raises returns to labor, which results in an increase of labor supply in Georgia both because more of the indigenous population joins the labor force and because labor migrates to Georgia from other states. The combined effect of the increase in capital accumulation and in labor supply increases Georgia's long-run economic growth rate. The resulting increases are economically significant. Fundamental state tax reform increases Georgia's compound growth rate in personal income by 0.6 percentage points relative to a prereform baseline.

The rest of the paper proceeds as follows. In the next section we provide background on the existing studies of fundamental tax reform and on the intuition behind our modeling strategy. The subsequent section discusses the current tax structure and further details about our simulated reforms. We describe our dynamic general equilibrium model in section 4 . That is followed in the subsequent section by a discussion of the benchmarking of the model. The results are presented in section 6 , and a summary and conclusion section completes the paper.

\section{BACKGROUND AND MODEL INTUITION}

Studies of the effect of fundamental national tax reform have generally used dynamic simulation models in a closed economy framework. Altig et al. (2001), for example, construct a closed economy, dynamic life-cycle simulation model to explore the welfare and macroeconomic effects of five fundamental national tax reforms. Their model is an enhanced version of the Auerbach and Kotlikoff (1987) model that incorporates intra- and intergenerational inequality in the manner of Fullerton and Rogers (1993). An earlier overview of the use of dynamic CGE models for the analysis of tax policies is provided by Pereira and Shoven (1988). Although they address a much earlier literature than that reflected in our paper, their overall reasoning for the importance of dynamic modeling is similar to ours. Tax reforms that impact income will necessarily have an effect on savings and investment. Savings behavior therefore needs to be endogenously determined as part of inter-temporal optimization, leading to the need for a dynamic model.

The models used to estimate the impact of fundamental U.S. national tax reform are generally inappropriate for analyzing the impact of tax reform at the state level for at least two

(C) Southern Regional Science Association 2015. 
reasons. First, the assumption of a closed economy is inappropriate for analyzing state-level reforms. Altig et al. (2001) contend that assuming a closed economy understates the potential welfare and output gains from tax reform. Their conclusion is consistent with that of Mendoza and Tesar (1998) who compare results from simulations of both a closed and an open economy. They find that the welfare gain from fundamental national tax reform is about one-third larger in an open-economy model than in a closed one. Ballard (2002) describes how estimates of the economic effects of fundamental national tax reform change when the foreign sector is modeled. Although results depend on exactly how international capital flows are modeled, he concludes that an open economy model increases the estimated gain in welfare. ${ }^{6}$ This open economy effect is likely to be even more pronounced when evaluating state tax reforms as opposed to national tax reforms because intra-national factor mobility is much greater than international factor mobility.

Second, the replacement tax being considered in state tax reforms - an expanded sales tax base and increase in the sales tax rate-is not the sort of consumption tax that is typically contemplated in fundamental national tax reforms. State sales taxes generally do not tax all final goods and services and include some business inputs in the sales tax base. Ring (1999), and more recently Neubig et al. (2004), estimate that the business share of state sales taxes constitute more than 40 percent of total state sales tax receipts. In their seminal article on optimal taxation, Diamond and Mirrlees (1971) show that it is not efficient to tax business inputs. Given the distortionary nature of state sales taxes, its use as a replacement tax for the state income tax is expected to have a smaller effect on economic growth and welfare than a broad-based consumption tax of the sort contemplated in fundamental national tax reforms. While we cannot simulate the sales tax base in a way that reflects the myriad of potential distortions, for example, we are not able to model in a meaningful way a sales tax that is imposed on intermediate goods, we do account for sales tax exemptions on many final purchases of goods and services.

Using an open economy model will relieve the underestimation noted in Altig et al. (2001), but that effect will, in part, be offset by the effects of the generally more distortionary state sales tax expansion. Whether the benefits from state tax reform of the type contemplated here are larger or smaller than those from national level but closed general equilibrium models is an open question. Furthermore, our model allows us to gauge the effect of tax reform not only on Georgia's economy but also its effect on the economies of five comparison states that together form an economic region.

There are several papers that use simulation models to analyze state tax changes in the U.S. context, including Morgan, Mutti and Partridge (1989), Berck, Golan and Smith (1997), Waters, Holland and Weber (1997), Baum (1998), Edmiston (2002), Julia-Wise, Cooke and Holland (2002), Cutler and Strelnikova (2004), and Faulk, Thaiprasert and Hicks (2010). These papers employ static models and typically consider only two regions, the reform state and the ROUS. Furthermore, none of these studies consider fundamental state tax reform, which is the focus of this study.

There is also a literature using multiregional CGE models to estimate the impact of subnational fiscal reforms in other federal countries, specifically Australia and Germany. Hirte (1998) uses a regional CGE model of the German economy to investigate the welfare effects of a

\footnotetext{
${ }^{6}$ Not all national models assume a closed economy; for example, Auerbach (1996) uses the Auerbach and Kotlikoff (1987) dynamic simulation model in an open economy framework.
}

(C) Southern Regional Science Association 2015. 
proposal to introduce state labor income tax supplements (Wissenschaftlicher Beirat beim Bundesfinanzministerium). Their regional CGE model consists of eleven regions, two production sectors, namely a public good and a private good as well as an intermediate good. Capital is supplied inelastically by the regional households and is perfectly mobile between states. Labor is supplied elastically by households and is intersectorally mobile but immobile between regions. They model a two-tier federal system with an equalization grant and significant tax sharing system that is identical to the existing German system. They find that a higher degree of fiscal autonomy is not welfare improving in the German case.

Giesecke (2003) uses a regional CGE model to examine whether Tasmania can use fiscal policy to reverse its declining share in the national share of output. More specifically, he examines whether Tasmania could use budget neutral tax policy to materially influence Tasmania's forecasted decline in the share of national output. For this purpose, Giesecke uses a dynamic two-region CGE model: Tasmania and the rest of Australia. There are 37 commodities in each region, and two-tiers of government. There is no interregional trade in this model, so that the only link between the two regional economies is via the effects of interregional migration on regional populations. Dynamics are modeled as a sequence of single-period equilibria via stockflow relationships. He finds that even when Tasmania completely eliminates the payroll tax and replaces it with a direct tax on households, the impact on the forecast for Tasmania's share of national activity is not large.

We conclude this section with an overview of the model; Section 4 provides the details of the model. As previously noted, we use a multiregional, dynamic, open economy, nonArmington, general equilibrium model. The model includes Georgia, five comparison states, and the ROUS. It accounts for the federal tax system and international trade and financial capital flows. The non-Armington approach is described in greater detail below, but we note here that this approach permits physically similar intermediate and final goods to be treated as perfect substitutes when traded across states. Thus, we do not have to estimate elasticities of substitution between Georgia peanuts and Alabama peanuts, for example. Avoiding the use of interregional elasticities of substitution for each industry relieves us of two serious problems. First, we do not have to estimate elasticities, ${ }^{7}$ and second, their inclusion would make the computational requirements of the model very large.

It should be noted that we do not claim that our non-Armington approach is appropriate for all or even most general equilibrium modeling exercises. Rather, it may be useful for certain trade and regional models within which there is a high degree of substitution between traded goods. For example, if there is a high degree of commonality across regions in the impact of economic shocks on traded goods, then the assumption of perfect substitutability may be suitable. Thus, given the sort of broad tax shocks that we are considering in this paper, we would claim that our non-Armington assumption is justified. In addition, non-Armington may also be appropriate in cases where either there is a high degree of substitutability between traded goods, or where it is not possible to measure the elasticities of substitution between those goods. For example, Feltenstein and Plassmann (2008) look at trade in intermediate goods in the ASEAN countries. A large portion of this trade is in goods such as computer chips and monitors for

\footnotetext{
${ }^{7}$ Turner (2012) estimates U.S. interregional trade elasticities for some commodity groups for Illinois vis-à-vis the ROUS, and is the only source of such elasticities that we are aware of. They do show that many traded goods are imperfect substitutes. This does not preclude the possibility that in certain situations, such as our, and with high degrees of aggregation, the non-Armington assumption may be suitable.
}

(c) Southern Regional Science Association 2015. 
which there is a very high degree of substitutability. Thus the non-Armington approach proved useful in this case. Finally, when there is a high degree of aggregation in traded goods in similar regions, such as the states in this model, the assumption of perfect substitutes may be a satisfactory approximation to reality.

The model provides for international trade in goods and financial capital, but the U.S. is treated as a closed economy in terms of labor and capital mobility. Georgia, the state that is adopting the tax policy reforms, and the five comparison states and the ROUS are treated as open economies in terms of trade in goods and services and factor mobility between regions. Since distance (transportation cost) is not modeled, the location of the states does not matter in this model. As we simulate the reform, we maintain revenue neutrality rather than budget neutrality to focus the analysis on the effect of tax reform on economic growth and to be consistent with the actual tax reform proposals. The reforms that we simulate in this study involve expanding Georgia's sales tax base by adding services to the base and increasing the sales tax rate. These revenues are used to reduce or eliminate Georgia's CIT and PIT. Prior to the tax reform, as reported in Table 1, the percentage of state tax revenue collected with capital taxes (including property taxes), personal income tax, and sales tax are 37.7 percent, 26.5 percent, and 35.8 percent, respectively.

\section{TAX BACKGROUND}

We choose Georgia for our simulated reform in part for convenience but also because Georgia is considering reducing the PIT rate and recovering the lost revenue by broadening the sales tax base to include services. The choice of the five comparison states is based in part on convenience as well; however, we also want to have a diverse set of states. The comparison states are the five states bordering Georgia. There is considerable heterogeneity in the size distribution of these five comparison states, with some larger and some smaller than Georgia, and interesting differences in their economic and tax structures. For example, Florida and Tennessee do not have state income taxes. Finally, together the six states represent a functional regional economy.

Before describing the details of the model and discussing the simulation results, we proceed below by briefly describing the six states that are the focus of this study. As reported in Table 1, Florida has the largest economy in terms of gross state product (GSP) of the six states at $\$ 737.1$ billion, which is nearly twice that of Georgia. These six states account for 15 percent of the GDP of the United States. In column 2 of Table 1, we report state and local government expenditures as a share of GSP by state. These shares range from 14 percent in North Carolina to 18.2 percent in South Carolina. Except for Alabama and South Carolina, the share of state and local expenditures in GSP is less than the average share for the ROUS. This is consistent with the reputation of this region for being fiscally conservative.

As reported in column 3 of Table 1, there is considerable diversity in the tax structures of these six states. Florida raises the most tax revenue as a share of state GDP (9 percent), with Tennessee raising the smallest share ( 7 percent). Florida does not have a PIT and makes up the forgone revenue by collecting a larger share of total tax revenue from capital taxes than the other five states. Aside from a small tax on capital gains, Tennessee also lacks a PIT but, in contrast to Florida, Tennessee recovers the forgone revenue by collecting a larger share of revenue from the sales tax than the other five states. 
Table 1: Size of State Economies and Tax Structure Prior to Reform

\begin{tabular}{|c|c|c|c|c|c|c|}
\hline \multirow[b]{2}{*}{ Region } & \multirow[b]{2}{*}{$\begin{array}{c}\text { Gross State } \\
\text { Product (GSP) } \\
\text { (Billions \$'s) } \\
(1) \\
\end{array}$} & \multicolumn{2}{|c|}{ Share in GSP of: } & \multicolumn{3}{|c|}{ Share in Total Tax Revenue of: } \\
\hline & & $\begin{array}{c}\text { State and } \\
\text { Local } \\
\text { Expenditures } \\
\text { (Percent) } \\
(2) \\
\end{array}$ & $\begin{array}{c}\text { State and } \\
\text { Local Tax } \\
\text { Revenue } \\
\text { (Percent) } \\
(3) \\
\end{array}$ & $\begin{array}{c}\text { Capital } \\
\text { Taxes } \\
\text { (Percent) } \\
(4) \\
\end{array}$ & $\begin{array}{c}\text { Sales } \\
\text { Taxes } \\
\text { (Percent) } \\
(5) \\
\end{array}$ & $\begin{array}{l}\text { Personal } \\
\text { Income } \\
\text { Tax } \\
\text { (Percent) } \\
(6) \\
\end{array}$ \\
\hline Alabama & 169.1 & 16.5 & 7.7 & 31.3 & 46.2 & 22.5 \\
\hline Florida & 737.1 & 14.1 & 9.0 & 53.5 & 46.5 & - \\
\hline Georgia & 398.6 & 14.2 & 7.8 & 37.7 & 35.8 & 26.5 \\
\hline North Carolina & 411.4 & 14.0 & 7.6 & 33.2 & 34.7 & 32.1 \\
\hline South Carolina & 160.6 & 18.2 & 8.0 & 42.8 & 34.2 & 23.0 \\
\hline Tennessee & 246.4 & 14.4 & 7.0 & 40.4 & 58.3 & 1.4 \\
\hline Rest of the USA & $11,995.8$ & 16.2 & 9.0 & 43.7 & 32.2 & 24.1 \\
\hline USA & $14,119.0$ & 16.0 & 8.9 & 43.6 & 33.7 & 22.7 \\
\hline
\end{tabular}

Source: Authors' calculations.

In short, there is considerable diversity in the size of these six state economies as well as in their tax structures. These differences make it essential to specify the individual structures of Georgia and the surrounding states, rather than simply treating all states as being economic replicas of one another.

\section{THE MODEL}

A feature of our model that most differentiates it from other general equilibrium models is our treatment of the substitutability of a good produced in multiple states. Thus, we start our discussion of the model with a description of this non-Armington approach to interstate trade.

\subsection{The Non-Armington Approach and Model Basics}

Differences in factor prices - and, more generally, differences in the costs of production across states that arise from different production functions-pose difficulties for multiregion general equilibrium models if these cost differences translate into different output prices. If goods from different states are perfect substitutes for each other, then consumers will acquire these goods only from the state with the lowest production cost and hence the lowest price. To avoid such corner solutions which imply, unrealistically, that each good is produced only in one state, models that allow for trade generally incorporate the so-called Armington assumption that goods produced in different regions or countries are imperfect substitutes for one another (see Armington, 1969). This assumption yields an intuitively plausible explanation for trade in seemingly identical final goods - for example, if consumers view German cars and Japanese cars as being distinct goods, then it is plausible that Germany and Japan would trade cars with each other. Hence, the Armington approach distinguishes final goods by physical characteristics as well as by place of origin. The Armington assumption has been used widely in computable general equilibrium (CGE) models since its introduction in the ORANI model of Australia (see Dixon et al., 1982). 
While the Armington assumption is appropriate as a motivation for international trade in final goods, we contend that the assumption is less appropriate as an explanation of interregional commodity flows in final goods and intermediate inputs between the states of the U.S. Many companies produce identical goods in different plants that are located in different states, but because the units produced in different states are indistinguishable from each other, consumers generally do not care (or know) in which state the particular unit that they acquire has been produced. For example, it is difficult to argue that Netflix customers who obtain DVDs by mail care whether their DVD requests were fulfilled by a facility located within their own state or some other state. Similarly, customers of Amazon.com are likely to be indifferent about the location of the warehouse that fills their orders.

Often goods that are produced by different companies in different states are identical or at least very close substitutes. For example, shipping is generally an intermediate input rather than a final product, and many recipients of mail orders are indifferent to whether their goods are shipped by UPS (whose headquarters are in Atlanta, Georgia) or by FedEx (whose headquarters are in Memphis, Tennessee). Frequently there is no substantial difference between, say, pieces of wood harvested and processed in different states that serve as intermediate inputs for, say, furniture. We accommodate these observations by assuming that otherwise identical commodities produced in different states are perfect substitutes for one another.

The limited availability of the data necessary to calibrate multi-region models often requires that researchers aggregate individual commodities into broad categories like "agriculture," "manufacturing," or "services." One might be concerned that such aggregate commodities are not perfectly substitutable since the mix of potatoes and corn, for instance, in "agriculture" differs across states. If all of the components of an aggregate commodity have identical price elasticities, for example, and are perfectly substitutable, then the aggregate will have that same elasticity. If, however, the components of a category differ and are not therefore perfect substitutes for one another, aggregation may diminish those differences. To illustrate, consider the following. Assume that pork and beef are not perfect substitutes, nor are green beans and carrots. Still, it is possible that a meal of pork and green beans may be a closer substitute to a meal of beef and carrots than are the two types of meats and vegetables. In either case, at such levels of aggregation, we maintain that the degree of substitutability between commodities produced in different states is likely to be fairly high.

Furthermore, Plassmann (2005) provides evidence that policy analyses undertaken with models that assume infinite elasticities of interregional substitution yield very similar results to those that assume elasticities of interregional substitution as low as 5. Thus, even if commodities produced in different states are not perfect substitutes for each other, the assumption of perfect substitutability is likely to be a sufficiently close approximation, especially in models that aggregate individual commodities into fairly broad industry categories. Both the Armington and non-Armington approaches simplify the real world, and there is no empirical evidence as to which assumption produces a closer approximation to reality. We adopt the non-Armington assumption, in part, because we believe it better reflects the nature of traded goods and allows for wages to differ by industry and state, but also because it requires identifying fewer elasticities.

We provide a detailed description of the mathematics behind our non-Armington approach in Appendix A. In particular, we derive the "backwards solution method" that determines equilibrium price on the space of factor prices. Here we give the intuition behind our 
methodology and present other details of the model. Our solution algorithm proceeds as follows: consider a single sector-say manufacturing - that operates in all states. If manufacturing output in any state is a perfect substitute for the manufacturing output of other states, then the equilibrium price of manufacturing output must be identical across states. To establish such a single equilibrium price for manufacturing output, we begin with the manufacturing industry in a reference state. ${ }^{8}$ We follow the standard practice and assume that the manufacturing sector in each state has its own two-part production function. The first part uses a neoclassical production function that transforms substitutable factor inputs of capital and labor into value added

$$
V A_{i}=\left(\sum_{k=1}^{K} \alpha_{k} x_{i k^{\frac{\sigma}{\sigma-1}}}\right)^{\frac{\sigma-1}{\sigma}}
$$

where $V A_{\mathrm{i}}$ is value added in industry $i, x_{i k}$ is the quantity of input factor $k$ (either capital or labor) used in the production of good $i, \alpha_{\mathrm{k}}$ is the constant elasticity of substitution (CES) share parameter, and $\sigma$ is the elasticity of substitution between the primary factors, capital, and labor.

There is a single, perfectly mobile type of capital, while labor is both sector and state specific. The value of $\sigma$ is derived from the exercise of calibrating the base case to actual data. The cost of producing value added in industry $i$ is

$$
C_{i}=\sum_{k=1}^{K} \rho_{i k} x_{i k}
$$

where $\rho_{i k}$ is the price of the primary input factor $x_{i k}$. Industries minimize Equation (2) subject to Equation (1). Since capital is assumed to be perfectly mobile, we assume that it will have the same after-tax rate of return in every state and sector. Existing capital moves between states in response to differentials in after tax returns to capital. Households make decisions each period regarding the utility-maximizing level of savings and labor supply. These decisions depend positively on the rates of return to savings and to labor. Domestic savings and net financial capital inflows from abroad are assumed to be equal to gross physical investment. We assume a given depreciation rate for existing capital. Thus, net capital accumulation for the entire economy is equal to savings plus net financial capital inflows from abroad less the depreciation of the existing capital stock. Since all capital earns the same net of tax return, the location of where capital is used is not material, only the location of the owner matters for income determination.

The second part of the algorithm uses an input-output (I-O) matrix to describe intermediate inputs that are used in fixed proportions

$$
p=B(p)+V\left(p_{L}, p_{K}\right),
$$

where $p$ is the vector of output prices, $B(p)$ is the matrix of demands for intermediate inputs, and $V\left(p_{L}, p_{K}\right)$ is the vector of each industry's cost of producing value added from labor and capital under their respective prices. We use this two-part production function for the manufacturing industry in the reference state, together with the price of capital and the manufacturing wage in the reference state, to determine the output price of the manufacturing sector, for example.

We view this price as the equilibrium price of manufacturing output. Thus, we must ensure that the prices of manufacturing output in all states equal this equilibrium price. As noted above there is a single type of perfectly mobile capital with an identical price across states. Nevertheless, we assume that labor is, at least in the short run, immobile. We can then solve

\footnotetext{
${ }^{8}$ In the models that we describe below, we use "the rest of the United States" as the reference "state."
}

(C) Southern Regional Science Association 2015. 
backwards, in every other state, for the wage rate in manufacturing that implies zero economic profits and the same price of manufacturing output as in the reference state. This backwards solution method follows from the assumed constant returns to scale structure of production functions across states. Thus, given a price of capital (that is identical across states) and a set of wages for the industries in the reference state, our model yields an equilibrium solution with industry-specific output prices that are identical across states, a single price of capital, and stateand sector-specific wages. ${ }^{9}$

In addition to being an appropriate and useful assumption to describe interstate trade flows within the United States, the assumption of perfect substitutability offers substantial advantages over models that use the Armington assumption. Our model naturally accommodates the observation that wages differ across industries and states. While it is possible in principle to assume state-and-industry-specific labor in Armington models, such an assumption increases the dimensionality of these models. ${ }^{10}$ Models with large numbers of unknowns are difficult to solve numerically, and researchers commonly need to limit the number of regions for such technical considerations. The typical Armington version of our type of regional economy would have a single type of labor for each region. Hence, there would be a single wage rate for all sectors in a region, which forces us to overlook the relative wage effects of different fiscal policies. Avoiding the Armington assumption makes it straightforward to solve large models with many regions and imperfectly mobile labor. ${ }^{11}$ In contrast, Armington models that describe trade in intermediate inputs need to employ an I-O matrix that distinguishes all intermediate inputs by region of origin; such I-O matrices are rarely available. ${ }^{12}$ An alternative approach is to have substitution in I-O coefficients, which presents an overwhelming computational problem. Of course, it is true that modern computers and algorithms can solve very large models. Still, the data requirements of estimating the cross-price elasticities in both production (coefficients in the I-O matrix) and in consumption are very high. In the case of international trade models where disaggregated data are available on trade in goods, such estimation may, in principle, be possible. In a state-level regional model, such as ours, such data on trade between regions are unavailable.

\subsection{Production and Factors}

We aggregate all commodities into twelve industries and assume that all output is produced with a combination of intermediate inputs as well as labor and capital as value added (see Equation 1). ${ }^{13} \mathrm{We}$ follow the common practice of describing the structure of intermediate inputs with an I-O matrix, and we therefore assume that intermediate inputs enter the production process in fixed proportions.

\footnotetext{
9 We solve the model using the algorithm described in Plassmann (2005) and Feltenstein and Plassmann (2008). The earliest version of such an algorithm was developed in Feltenstein (1997) for a single state embedded in a country.

${ }^{10}$ For example, an Armington model that incorporates state- and industry-specific wages and that describes seven "states" and twelve industries per state needs to be solved for $7 \times 12=84$ unknown wages. In contrast, our non-Armington model has only one unknown wage per industry in the reference state (that is, twelve), regardless of the number of states, because the equilibrium wages in all other states are determined endogenously from the twelve prices of labor and the price of capital.

${ }^{11}$ Dixon et al. (2012) implement and solve a 51-region Armington model of the United States by assuming that all users of a good in a particular region acquire this good in common proportions from all regions.

12 For additional discussion, see Feltenstein and Plassmann (2008, pp. 909-13). We have data for each of our regions via the IMPLAN state-specific I-O matrices. These matrices do not show substitution in intermediate inputs to production. Thus, agricultural inputs to Georgia production are a composite commodity. We cannot know the state-by-state composition of these inputs from the IMPLAN matrices.

13 The twelve industries are (1) agriculture, (2) mining, (3) utilities, (4) construction, (5) manufacturing, (6) trade, (7), transportation, (8) financial services, (9) real estate, (10) services, (11) federal government, and (12) state and local government.
}

(C) Southern Regional Science Association 2015. 
We include land as part of "capital" in the value added functions of all sectors to avoid the difficulties of determining industry-specific use of land. Although the assumption of perfect capital mobility abstracts from the existence of immobile capital like land and structures and partially mobile capital like large machines, the lack of information regarding the annual flow of capital among states and industries makes it impossible to calibrate "migration functions" for capital. Nonetheless, for the price of capital to be equal across states we only need capital at the margin to be mobile, an interpretation of perfect mobility that is consistent with that of Randolph (2006). Furthermore, the thorough integration of the states in a common market, like the U.S. economy, does support the assertion that the price of capital between states may not vary by large margins. We should also note that the assumption is an abstraction which, as might be feared, does not lead to corner solutions. In our solution, method output levels and, hence, demand for capital are constrained by labor supplies in each region. Combined with decreasing returns to capital, this will ensure that at equilibrium we avoid corner solutions in which all capital flows to a single region, no matter how many time periods the model has (See Appendix A). With regard to labor we assume that each state has twelve representative agents who allocate their labor across the state's twelve industries. These agents represent the initial workforce in each industry, but fractions of each agent can migrate across industries and states between any two periods, taking their labor endowments and assets with them. Each representative agent receives income from supplying his labor and assets, as well as from transfers from the federal government and state and local governments.

During any given period, labor supply is specific to individual industries in individual states so that wages differ across industries and states. We permit workers to migrate across states and across industries after each period, where the migration depends upon relative wages of the different states. We use observed changes in employment across industries and states to calibrate the labor migration functions; these migration functions introduce frictions that prevent instant wage equalization across industries and regions and also prevent sudden large movements of labor across states.

\subsection{Consumption, Labor Supply, and Dynamics}

We model the consumption-saving decision problem of each representative agent with the standard set of nested constant elasticity of substitution (CES) and Cobb-Douglas utility functions. ${ }^{14}$ Specifically, we assume that each representative agent maximizes the following lifetime utility function:

$$
\mathrm{U}=\left\{\sum_{t=0}^{\infty} \beta(t) C(t)^{\frac{\rho-1}{\rho}}\right\}^{\frac{\rho}{\rho-1}}
$$

where $C(t)$ is consumption at time $t$, the $\beta(t)$ 's are the CES share parameters that are related to the agent's pure rate of time preference, and $\rho$ is the elasticity of intertemporal substitution. ${ }^{15}$ As before, $\rho$ is derived as part of the calibration exercise. Each agent first allocates his lifetime wealth so as to finance consumption in each period according to equation 4; he then decides how to divide the chosen $C(t)$ among consumption of goods and leisure in each period $t$. Finally, he

\footnotetext{
${ }^{14}$ See, for example, Ballard, Shoven, and Whalley (1985).

${ }^{15}$ We determine the rates of time preferences numerically as part of the solution algorithm so that a family's long-run saving rate converges to a stable value, given their observed ratio of marginal utility to the price index in period 0 . The algorithm is described in detail in Tideman et al. (2002). The advantage of this approach is that the periods can be solved sequentially while maintaining the assumption of perfect foresight, which makes it possible to solve the model for a larger number of periods.
}

(C) Southern Regional Science Association 2015. 
decides, based on a Cobb-Douglas utility function, how to divide the total consumption of goods among the output from the 12 industries. Since we assume that consumers consider otherwise identical goods produced in different states as perfect substitutes, we do not need to specify how they divide their consumption of industry output among the units produced in different states. Income includes labor income and the returns to holding capital and financial assets, net of taxes and transfers. We assume that capital is owned by the residents of the state in which the capital is located.

The dynamics of capital and labor, and corresponding market clearing assumptions, may be described as follows. To simplify notation, we will suppose that we are in a two-period model. The consumer's problem is then:

$$
\operatorname{Max} U\left(x_{1}, x_{L 1 j q}, x_{2}, x_{L 2 j q}\right)
$$

such that:

$$
\begin{aligned}
& \left(1+t_{i}\right) P_{i} x_{i}+P_{L i j q} x_{L i j q}+P_{B i} x_{B i}=C_{i} \\
& P_{K 1} K_{0}+P_{L 1 j q} L_{1 j q}+r_{0} B_{0}+P_{B 1} B_{0}+T R_{1}=N_{1} \\
& P_{K 2}(1+\delta) K_{0}+P_{L 2 j q} L_{2 j q}+r_{1} x_{B 1}+P_{B 2} x_{B 1}+T R_{2}=N_{2} \\
& C_{i}=N_{i} \\
& P_{B 2} x_{B 2}=S N_{2}
\end{aligned}
$$

where:

$P_{i} \quad=$ price vector of consumption goods in period $i$

$x_{i} \quad=$ vector of consumption in period $i$;

$C_{i}=$ value of aggregate consumption in period $i$ (including purchases of financial assets);

$N_{i} \quad=$ aggregate income in period $i$ (including potential income from the sale of real and financial assets);

$t_{i} \quad=$ vector of value added tax rates in period $i$;

$P_{\text {Lijq }}=$ price of labor in sector $j$ in region $q$ in period $i$;

$x_{L i j q}=$ demand for leisure in sector $j$ in region $q$ in period $i$;

$P_{K i}=$ price of capital in period $i$;

$K_{0} \quad=$ initial holding of capital;

$\delta \quad=$ rate of depreciation of capital;

$P_{B i}=$ discount price of a bond in period $i$;

$r_{i}=$ domestic interest rate in period $i$;

$x_{B i}=$ demand for bonds in period $i$;

$\mathrm{TR}_{\mathrm{i}}=$ transfer payments from the government in period $i$;

$s \quad=$ long run savings rate.

(C) Southern Regional Science Association 2015. 
Thus, each consumer demands bonds as an instrument for intertemporal optimization via consumption smoothing. The final equation, $P_{B 2} x_{B 2}=s N_{2}$, is a closure rule for the model that says that savings (purchases of bonds) in the final period are determined by the long-run savings rate applied to the final period's income. This will also determine investment in the final period as part of the same closure rule. An interesting experiment would be to see how alternative closure rules might change our simulation results; however, this is beyond the scope of the current paper.

Bonds are created by the government, described in the next section, and by private investors as an instrument to finance capital formation. Private bond issuance is determined by equating current borrowing to the present discounted value of returns on investment. Suppose that $H_{1}$ is the quantity of capital created in period 1 by a private sector firm. Let $C_{H 1}$ be the amount borrowed to finance this investment in period 1. Then by free entry we must have:

$$
C_{H 1}=\sum_{i=2}^{N} \frac{P_{K i}\left(1-t_{K i}\right)(1-\delta)^{i-2} H_{1}}{\prod_{j=1}^{i-1}\left(1+r_{j}\right)}
$$

where the other terms in Equation 6 are defined above. Accordingly, the after tax returns to the depreciated quantity of capital in each period are discounted by the market interest rate, which is determined endogenously as part of the equilibrium solution. The quantity of bonds issued by the firm is then given by $y_{B} 1$ where:

$$
y_{B 1}=\frac{C_{H 1}}{P_{B i}} .
$$

We thus define the dynamics of capital formation by the above equation combined with the equilibrium conditions that $\sum x_{B i}=\sum y_{B i}$, where the left-hand summation is over all consumers in all regions, and the right summation is over all firms plus debt issuance by the governments.

We should note that our specification of the dynamics of capital formation corresponds to the standard macroeconomic formulation of forward looking representative agents who optimize over time. This approach allows us to determine endogenous rates of growth, capital formation, and interest rates, something that would not be possible to do correctly with the type of sequenced equilibria that are used in some CGE models. In summary, capital stock grows over time due to saving and net financial inflows from abroad, while labor supply can vary over time due to changes in real wages.

\subsection{Governments}

All governments make transfers to consumers, invest in government assets (bonds), and demand intermediate inputs to produce public goods. They finance these expenditures by levying taxes on the use of capital, which we consider to be corporate income taxes as well as property taxes, personal income taxes on labor and asset income, sales taxes on the consumption of goods, as well as by issuing public debt. Since the model abstracts from risk, consumers view the holding of public debt and investment in new capital as equivalent. Thus, the interest on public debt equals the equilibrium return to holding existing capital and to investment in new capital. ${ }^{16}$ We account for subsidies to different industries by calibrating the effective tax rates on corporate income in these industries accordingly. Furthermore, in calculating state CIT rates we account

\footnotetext{
${ }^{16}$ All capital that is created during the time period of the model is represented by private debt that was created to finance the capital formation. Because we abstract from risk, the return on this private debt is the same as on public debt.
}

(C) Southern Regional Science Association 2015. 
for differences across industries in the relative importance of corporations in production versus non-corporations. The federal government makes transfers to and levies taxes on firms and consumers in all states, while each state government makes transfers to and levies taxes on firms and consumers in its own state only.

Income tax is applied to the returns to labor and capital of residents in the state. More specifically, the income tax on wages is treated as a withholding tax that is paid directly by the firm that employs the labor. The income on returns to capital is paid directly by the consumer. State sales taxes are imposed on final goods and services, and thus we do not account for the potential pyramiding of state sales taxes.

Tax rates are average effective tax rates, calculated as actual state and local tax revenue for the specific tax in the base year divided by the implied tax base in the base year. We do not account for increasing marginal tax rates.

An issue that must be addressed is how to model the behavior of governments over time. We assume that all tax rates, other than for our exogenous tax policy change, remain unchanged over time; that government spending on public goods is proportional to each state's value of production; and that government transfers, on the other hand, are proportional to each state's total income. We calibrate the values of government spending and government investment for all periods in the base case scenario, and we then use these calibrated values for the periods in the counterfactual analyses that assume different tax rates in Georgia. Thus tax policies may vary, but government expenditures are fixed. Governments can run surpluses or deficits. Other approaches to modeling government expenditures are certainly meaningful, but would distract from our focus on tax instruments.

We model the following revenue neutral tax reforms, where revenue neutrality means that tax revenue in the first year of any tax reforms equals the tax revenue in the first year of the baseline. For Tax Reform Option A, we expand the sales tax base to include purchases of services and use the revenue to reduce the PIT rate. For Tax Reform Option B, we add services to the sales tax base and increase the sales tax rate to recover the revenue lost by the elimination of the PIT. Tax Reform Option C is similar to Option B except that the sales tax rate is increased to recover the revenue lost from the elimination of both the CIT and PIT. Note that Option C eliminates the CIT but not the property tax on capital.

\subsection{The Rest of the World}

We permit the United States to run a trade deficit with the rest of the world and assume that the rest of the world supplies any quantity of import demand at the prices that prevail in the United States. Consumers finance their demand for imports by selling fractions of their capital stock and of their holdings of government debt to foreigners. Foreigners use their asset revenue and the proceeds from net exports to finance the governments' budget deficits and to invest in new capital in the United States.

\subsection{Data}

The data are for the year 2009. This choice of year was made in part because that was the year that the proposal to eliminate the income tax in Georgia was first made, and because that is the most recent data that were available when we started this project. To the extent that the intervening Great Recession reduced the level of economic activity below that which would otherwise have prevailed in 2009 , we would expect that the magnitudes of the effects of the tax 
change would be smaller. Then again, we would not expect that the effect of the tax policy on the growth rates of the various outcome measures would be affected by the Great Recession.

The input-output matrices are from MIG's IMPLAN (2009). Other data were obtained from the Bureau of Census' Government Finances webpage (http://www.census.gov/govs/ financegen), and the Bureau of Economic Analysis' (BEA) national and regional webpages (http://www.bea.gov). The data and behavioral assumptions reflect annual values. Thus, we interpret a period to be equivalent to a year, i.e., the time required to produce a year's output. As noted above, we follow the standard practice of measuring tax rates as the ratio of tax revenue to the tax base. BEA and IMPLAN data are used to calculate some of the model's parameters. Other parameters, for example, the elasticity of substitution between consumption of goods and leisure and the intertemporal elasticity of substitution are derived from calibrating the model to historical data, but we require that these elasticities be consistent with the range of values that are found in the literature. The study data file is available from the authors upon request.

\section{BASELINE SIMULATION}

We begin by briefly describing the baseline simulation that we use as a benchmark to gauge the effect of Georgia's tax reforms on its economy, on the economies of each of the five comparison states, and on the economy of the ROUS. Recall that the model is calibrated to a single year. Hence, the baseline simulation is used for purposes of comparison and should not be interpreted as a statistical forecast of future performance, which obviously it is not.

Table 2 reports the results of the baseline simulation for four key macroeconomic variables, namely personal income, consumption of goods, labor supply, and demand for capital by state and by period. We report the results for ten periods since the changes in period-to-period growth rates are small for additional periods. We index each endogenous variable by setting it equal to 100 in the base year, which is reported in the column labeled 0; thus the percent growth from the base year is easily interpreted from the values in Table 2. North Carolina's economy out performs the other five states as well as the ROUS over the ten periods. Personal income in North Carolina increases by slightly more than 50 percent over the ten periods, which is equivalent to an average annual increase of 4.2 percent. Using the growth in personal income as a performance benchmark, Georgia's economy ranks second among the six states with a compound growth rate of 3.4 percent over the 10 periods. The compound growth rates of personal income in the baseline simulation for the remaining states and that of the ROUS are substantially smaller than that of North Carolina and Georgia. Georgia's average simulated growth rate in per capita (worker) income is 2.29 percent. In contrast, Georgia's average growth rate in real per capita income for the period 1990 to 2008 is 1.24 percent. Thus, our model generates a higher average growth rate in personal income per capita than Georgia's recent historical experience.

It is thus difficult to draw a general conclusion as to how well our specification represents the true dynamics of the states we are modeling. The model is calibrated to a single year, as it is not possible to replicate dynamic paths for all states simultaneously. In reality, policy parameters change from year to year, so any simulation in which we assume that these parameters remain constant cannot hope to perfectly replicate historical dynamic paths. In fact, such difficulties would remain even in a model of a single country. In general, attempts to replicate the dynamic path of a macro-economy can yield only an approximation, so that a subjective judgment needs 
Table 2: Baseline Simulation of Key Macroeconomic Variables by State and by Period

\begin{tabular}{|c|c|c|c|c|c|c|c|c|c|c|c|}
\hline \multirow[b]{2}{*}{ State } & \multicolumn{11}{|c|}{ Period } \\
\hline & $\mathbf{0}$ & 1 & 2 & 3 & 4 & 5 & 6 & 7 & 8 & 9 & 10 \\
\hline & \multicolumn{11}{|c|}{ Personal Income } \\
\hline Alabama & 100.0 & 101.4 & 103.4 & 106.1 & 109.3 & 112.7 & 116.2 & 119.8 & 123.6 & 127.5 & 131.6 \\
\hline Florida & 100.0 & 101.2 & 103.0 & 105.2 & 108.0 & 110.8 & 113.6 & 116.5 & 119.3 & 122.3 & 125.2 \\
\hline Georgia & 100.0 & 102.0 & 105.0 & 108.4 & 112.3 & 116.4 & 120.6 & 125.0 & 129.6 & 134.3 & 139.3 \\
\hline North Carolina & 100.0 & 102.7 & 106.7 & 111.2 & 116.2 & 121.4 & 126.7 & 132.3 & 138.1 & 144.2 & 150.6 \\
\hline South Carolina & 100.0 & 100.9 & 101.8 & 103.4 & 105.4 & 107.5 & 109.6 & 111.7 & 113.9 & 116.0 & 118.1 \\
\hline Tennessee & 100.0 & 100.8 & 101.6 & 103.1 & 105.0 & 107.1 & 109.2 & 111.3 & 113.5 & 115.6 & 117.8 \\
\hline Rest of USA & 100.0 & 101.3 & 103.6 & 106.1 & 108.7 & 111.3 & 113.9 & 116.5 & 119.2 & 121.8 & 124.5 \\
\hline \multirow[t]{2}{*}{ USA } & 100.0 & 101.4 & 103.6 & 106.2 & 108.9 & 111.6 & 114.3 & 117.1 & 119.9 & 122.7 & 125.6 \\
\hline & \multicolumn{11}{|c|}{ Consumption of Goods } \\
\hline Alabama & 100.0 & 101.1 & 102.9 & 105.5 & 108.7 & 112.1 & 115.6 & 119.2 & 123.0 & 127.0 & 131.1 \\
\hline Florida & 100.0 & 100.7 & 102.2 & 104.2 & 106.9 & 109.7 & 112.5 & 115.2 & 118.0 & 120.9 & 123.8 \\
\hline Georgia & 100.0 & 101.8 & 104.7 & 108.2 & 112.2 & 116.4 & 120.7 & 125.2 & 129.9 & 134.8 & 139.9 \\
\hline North Carolina & 100.0 & 102.7 & 106.8 & 111.7 & 117.0 & 122.6 & 128.4 & 134.4 & 140.7 & 147.3 & 154.2 \\
\hline South Carolina & 100.0 & 100.5 & 101.1 & 102.4 & 104.2 & 106.2 & 108.1 & 110.0 & 111.9 & 113.9 & 115.8 \\
\hline Tennessee & 100.0 & 100.5 & 101.0 & 102.2 & 104.0 & 106.0 & 107.9 & 109.9 & 111.8 & 113.8 & 115.8 \\
\hline Rest of USA & 100.0 & 101.0 & 103.2 & 105.6 & 108.1 & 110.6 & 113.2 & 115.7 & 118.2 & 120.8 & 123.3 \\
\hline \multirow[t]{2}{*}{ USA } & 100.0 & 101.0 & 103.2 & 105.7 & 108.3 & 110.9 & 113.6 & 116.3 & 119.0 & 121.8 & 124.5 \\
\hline & \multicolumn{11}{|c|}{ Labor Supply } \\
\hline Alabama & 100.0 & 100.7 & 100.5 & 100.7 & 101.3 & 102.1 & 103.1 & 104.0 & 105.1 & 106.2 & 107.3 \\
\hline Florida & 100.0 & 100.8 & 100.7 & 100.5 & 100.7 & 101.0 & 101.4 & 101.8 & 102.2 & 102.6 & 103.0 \\
\hline Georgia & 100.0 & 101.3 & 102.0 & 102.7 & 103.7 & 104.8 & 106.0 & 107.2 & 108.5 & 109.7 & 111.1 \\
\hline North Carolina & 100.0 & 100.7 & 101.1 & 101.7 & 102.6 & 103.7 & 104.9 & 106.2 & 107.6 & 109.0 & 110.6 \\
\hline South Carolina & 100.0 & 100.8 & 100.4 & 100.1 & 100.3 & 100.8 & 101.2 & 101.7 & 102.2 & 102.7 & 103.1 \\
\hline Tennessee & 100.0 & 100.7 & 100.3 & 99.9 & 100.1 & 100.5 & 100.9 & 101.3 & 101.8 & 102.2 & 102.6 \\
\hline Rest of USA & 100.0 & 100.9 & 101.5 & 102.2 & 102.7 & 103.2 & 103.8 & 104.3 & 104.8 & 105.3 & 105.8 \\
\hline \multirow[t]{2}{*}{ USA } & 100.0 & 100.9 & 101.5 & 102.0 & 102.6 & 103.1 & 103.6 & 104.2 & 104.8 & 105.3 & 105.9 \\
\hline & \multicolumn{11}{|c|}{ Demand for Capital } \\
\hline Alabama & 100.0 & 102.8 & 105.8 & 109.4 & 113.6 & 118.0 & 122.8 & 127.8 & 133.1 & 138.5 & 144.2 \\
\hline Florida & 100.0 & 103.0 & 106.5 & 110.3 & 114.4 & 118.7 & 123.0 & 127.4 & 131.8 & 136.3 & 140.9 \\
\hline Georgia & 100.0 & 104.9 & 110.2 & 116.0 & 122.1 & 128.5 & 135.0 & 141.7 & 148.6 & 155.7 & 163.0 \\
\hline North Carolina & 100.0 & 105.3 & 111.2 & 117.8 & 124.8 & 131.9 & 139.3 & 147.0 & 155.0 & 163.3 & 172.0 \\
\hline South Carolina & 100.0 & 101.6 & 102.6 & 103.7 & 105.3 & 107.1 & 109.0 & 110.8 & 112.6 & 114.3 & 116.1 \\
\hline Tennessee & 100.0 & 101.5 & 102.2 & 103.2 & 104.8 & 106.6 & 108.4 & 110.2 & 112.0 & 113.7 & 115.5 \\
\hline Rest of USA & 100.0 & 101.9 & 104.1 & 106.3 & 108.5 & 110.7 & 112.9 & 115.1 & 117.3 & 119.4 & 121.6 \\
\hline USA & 100.0 & 102.2 & 104.6 & 107.1 & 109.6 & 112.2 & 114.8 & 117.4 & 120.0 & 122.7 & 125.3 \\
\hline
\end{tabular}

Source: Authors' calculations.

(C) Southern Regional Science Association 2015. 
to be made as to whether the model is a "good" replica of the actual economy. As an example of such a dynamic approximation, Appendix B gives an example of a two-period model applied to Australia. As we see, there is a reasonable, but not exact, approximation of the historical macroeconomic aggregates.

As might be expected, North Carolina and Georgia also lead the other states in the growth rate of consumption of goods and the growth rate in the demand for capital over the 10-period horizon of the baseline simulation. Finally, Georgia leads all other states and the ROUS in terms of the 10-period growth rate in labor supply. North Carolina ranks second in terms of the 10period growth rate in labor supply, followed by Alabama. The remaining regions have 10-period growth rates of labor supply in the 3 to 6 percent range.

\section{TAX REFORM SIMULATIONS}

We begin the discussion of our simulations by examining the effect of the tax reform options considered here on Georgia's tax composition. Table 3 shows the share of taxes by source and state in period 10 for the baseline and for each of the three tax reform options. As is evident in Table 3 and as one should expect, tax reform in Georgia has a negligible impact on the tax structures of the five comparison states. Therefore, we focus the discussion here on the effect of each of the three reforms on Georgia's tax structure.

Tax Reform Option A-broadening the sales tax base and a revenue neutral reduction in the PIT rate-results in a 92 percent decrease in the share of PIT revenue in total tax revenue relative to the baseline. The share of revenue from taxes on capital in total tax revenue is virtually unchanged; whereas, the share of sales tax revenue increases by 53 percent. Tax Reform Option B eliminates the PIT altogether, which therefore no longer contributes to total taxes, while the share of sales tax revenue in total tax revenue increases to 60 percent. As a result of this reform, there is only a slight decrease in the share of revenue from taxes on capital relative to the baseline. Finally, fundamental state tax reform, Tax Reform Option C, which is a repeal of both the CIT and PIT and a revenue neutral increase in the sales tax rate on the broadened sales tax base, has a surprising effect on Georgia's tax structure. Relative to the penultimate reform (the set of columns labeled Tax Reform B in Table 3) results in a slight decrease in the share of revenue from the sales tax and a slight increase in the share of revenue from taxes on capital. Since property taxes are modeled here as a tax on capital, repeal of the CIT has a positive effect on revenues from property taxes; hence, the increase in the share of revenue from taxes on capital, or, to be more precise, an increase in revenue from property taxes which are local taxes in Georgia.

We now examine the effect of each reform on the four macroeconomic variables used to describe the baseline simulation. We begin with the impact of adding services to Georgia's sales tax base and a revenue neutral decrease in the PIT rate; that is Option A. The results of this simulation are reported in Table 4.

As a result of this reform, personal income in Georgia increases from 139.3 in period 10 of the baseline simulation to 148.5 in period 10 of Option A. This is a 6.6 percent increase in personal income. In the baseline, the compound growth rate of personal income is 3.37 percent, which increases to 3.88 percent as a result of this reform. This is a 0.51 percentage point increase in the compound growth rate in personal income. In contrast, the growth rate in personal income declines in the five comparison states and the ROUS, with the largest decline in percentage terms 
Table 3: Tax Structure in Period 10 by State and by Tax Reform

\begin{tabular}{|c|c|c|c|c|c|c|c|c|c|c|c|c|}
\hline \multirow[b]{2}{*}{ State } & \multicolumn{3}{|c|}{--------Baseline---------- } & \multicolumn{3}{|c|}{-----Tax Reform A $\mathbf{A}^{1}$} & \multicolumn{3}{|c|}{------Tax Reform B²------ } & \multicolumn{3}{|c|}{-----Tax Reform C ${ }^{3}$} \\
\hline & $\begin{array}{c}\text { Capital } \\
\text { Tax }\end{array}$ & $\begin{array}{c}\text { Sales } \\
\text { Tax }\end{array}$ & PIT & $\begin{array}{c}\text { Capital } \\
\text { Tax }\end{array}$ & $\begin{array}{c}\text { Sales } \\
\text { Tax }\end{array}$ & PIT & $\begin{array}{c}\text { Capital } \\
\text { Tax }\end{array}$ & $\begin{array}{c}\text { Sales } \\
\text { Tax }\end{array}$ & PIT & $\begin{array}{c}\text { Capital } \\
\text { Tax }\end{array}$ & $\begin{array}{c}\text { Sales } \\
\text { Tax }\end{array}$ & PIT \\
\hline Alabama & 37.9 & 41.8 & 20.3 & 37.7 & 42.2 & 20.1 & 37.5 & 42.5 & 20.0 & 37.6 & 42.4 & 20.0 \\
\hline Florida & 56.6 & 43.4 & 0.0 & 56.5 & 43.5 & 0.0 & 56.4 & 43.6 & 0.0 & 56.4 & 43.6 & 0.0 \\
\hline $\begin{array}{l}\text { Georgia } \\
\text { North }\end{array}$ & 41.4 & 33.9 & 24.7 & 41.5 & 51.8 & 6.7 & 40.0 & 60.0 & 0.0 & 42.2 & 57.8 & 0.0 \\
\hline $\begin{array}{l}\text { Carolina } \\
\text { South }\end{array}$ & 36.3 & 33.7 & 30.0 & 36.1 & 34.1 & 29.8 & 35.9 & 34.3 & 29.7 & 36.0 & 34.2 & 29.8 \\
\hline Carolina & 43.1 & 33.7 & 23.2 & 43.1 & 33.9 & 23.0 & 43.0 & 33.9 & 23.0 & 43.1 & 34.0 & 23.0 \\
\hline Tennessee & 41.1 & 57.5 & 1.4 & 41.0 & 57.7 & 1.4 & 40.8 & 57.8 & 1.4 & 40.8 & 57.8 & 1.4 \\
\hline ROUS & 43.1 & 32.4 & 24.5 & 43.0 & 32.5 & 24.5 & 42.9 & 32.6 & 24.4 & 43.0 & 32.6 & 24.4 \\
\hline
\end{tabular}

Notes: ${ }^{1}$ Tax reform A: Broaden sales tax base to include services and a revenue neutral reduction in the PIT rate.

${ }^{2}$ Tax reform B: Eliminate the PIT and a revenue neutral increase in the sales tax rate on the broaden sales tax base.

${ }^{3}$ Tax reform C: Eliminate the PIT and the CIT and a revenue neutral increase in the sales tax rate on the broaden sales tax base. 
Table 4: The Effect of Tax Reform Option A on Key Macroeconomic Variables by State and by Period ${ }^{1}$

\begin{tabular}{|c|c|c|c|c|c|c|c|c|c|c|c|}
\hline \multirow[b]{2}{*}{ State } & \multicolumn{11}{|c|}{ Period } \\
\hline & $\mathbf{0}$ & 1 & 2 & 3 & 4 & 5 & 6 & 7 & 8 & 9 & 10 \\
\hline & \multicolumn{11}{|c|}{ Personal Income } \\
\hline Alabama & 100.0 & 101.2 & 103.0 & 105.7 & 108.7 & 111.8 & 115.1 & 118.4 & 121.9 & 125.4 & 129.0 \\
\hline Florida & 100.0 & 101.1 & 102.5 & 104.9 & 107.5 & 110.2 & 112.8 & 115.5 & 118.2 & 120.9 & 123.6 \\
\hline Georgia & 101.5 & 103.8 & 107.7 & 111.9 & 116.4 & 121.2 & 126.2 & 131.4 & 136.9 & 142.6 & 148.5 \\
\hline North Carolina & 100.0 & 102.6 & 106.3 & 110.7 & 115.5 & 120.4 & 125.5 & 130.8 & 136.3 & 142.0 & 148.0 \\
\hline South Carolina & 100.0 & 100.7 & 101.4 & 103.1 & 105.0 & 107.0 & 109.0 & 110.9 & 112.9 & 114.9 & 116.8 \\
\hline Tennessee & 100.0 & 100.6 & 101.2 & 102.7 & 104.6 & 106.6 & 108.5 & 110.5 & 112.4 & 114.3 & 116.3 \\
\hline Rest of USA & 100.0 & 101.3 & 103.6 & 106.1 & 108.5 & 111.0 & 113.5 & 116.1 & 118.6 & 121.1 & 123.6 \\
\hline \multirow[t]{2}{*}{ USA } & 100.1 & 101.4 & 103.7 & 106.2 & 108.8 & 111.4 & 114.0 & 116.7 & 119.4 & 122.1 & 124.8 \\
\hline & \multicolumn{11}{|c|}{ Consumption of Goods } \\
\hline Alabama & 100.0 & 101.1 & 102.9 & 105.6 & 108.7 & 112.0 & 115.4 & 119.0 & 122.8 & 126.7 & 130.7 \\
\hline Florida & 100.0 & 100.8 & 102.2 & 104.3 & 106.9 & 109.7 & 112.3 & 115.0 & 117.8 & 120.5 & 123.3 \\
\hline Georgia & 103.3 & 105.8 & 109.3 & 113.4 & 118.0 & 122.9 & 128.0 & 133.2 & 138.8 & 144.5 & 150.4 \\
\hline North Carolina & 100.0 & 102.7 & 106.8 & 111.7 & 117.0 & 122.5 & 128.2 & 134.2 & 140.4 & 146.9 & 153.7 \\
\hline South Carolina & 100.0 & 100.5 & 101.2 & 102.5 & 104.2 & 106.1 & 108.0 & 109.8 & 111.7 & 113.5 & 115.4 \\
\hline Tennessee & 100.0 & 100.5 & 101.1 & 102.3 & 104.0 & 105.9 & 107.8 & 109.7 & 111.6 & 113.5 & 115.4 \\
\hline Rest of USA & 100.0 & 101.1 & 103.3 & 105.7 & 108.1 & 110.6 & 113.0 & 115.5 & 118.0 & 120.4 & 122.9 \\
\hline \multirow[t]{2}{*}{ USA } & 100.1 & 101.2 & 103.4 & 105.9 & 108.5 & 111.1 & 113.7 & 116.3 & 119.0 & 121.7 & 124.4 \\
\hline & \multicolumn{11}{|c|}{ Labor Supply } \\
\hline Alabama & 100.0 & 100.3 & 99.9 & 100.0 & 100.5 & 101.3 & 102.1 & 102.9 & 103.8 & 104.7 & 105.7 \\
\hline Florida & 100.0 & 100.5 & 99.9 & 99.9 & 100.1 & 100.4 & 100.7 & 101.0 & 101.3 & 101.6 & 101.9 \\
\hline Georgia & 98.9 & 100.4 & 102.6 & 104.6 & 106.7 & 108.8 & 111.0 & 113.2 & 115.4 & 117.6 & 119.9 \\
\hline North Carolina & 100.0 & 100.4 & 100.4 & 100.9 & 101.7 & 102.7 & 103.8 & 105.0 & 106.3 & 107.8 & 109.3 \\
\hline South Carolina & 100.0 & 100.4 & 99.7 & 99.6 & 99.9 & 100.4 & 100.8 & 101.3 & 101.7 & 102.1 & 102.5 \\
\hline Tennessee & 100.0 & 100.4 & 99.5 & 99.4 & 99.7 & 100.1 & 100.5 & 100.8 & 101.2 & 101.6 & 102.0 \\
\hline Rest of USA & 100.0 & 100.9 & 101.5 & 102.1 & 102.6 & 103.1 & 103.6 & 104.1 & 104.5 & 105.0 & 105.5 \\
\hline \multirow[t]{2}{*}{ USA } & 100.0 & 100.8 & 101.4 & 101.9 & 102.5 & 103.0 & 103.5 & 104.1 & 104.6 & 105.2 & 105.7 \\
\hline & \multicolumn{11}{|c|}{ Demand for Capital } \\
\hline Alabama & 100.0 & 102.5 & 105.3 & 108.8 & 112.7 & 116.9 & 121.3 & 126.0 & 130.8 & 135.9 & 141.0 \\
\hline Florida & 100.0 & 102.8 & 106.2 & 110.1 & 114.1 & 118.3 & 122.5 & 126.7 & 130.9 & 135.2 & 139.5 \\
\hline Georgia & 100.0 & 105.2 & 111.9 & 118.9 & 125.9 & 133.1 & 140.5 & 148.0 & 155.8 & 163.8 & 172.0 \\
\hline North Carolina & 100.0 & 105.1 & 110.9 & 117.3 & 124.0 & 130.9 & 138.0 & 145.5 & 153.2 & 161.2 & 169.5 \\
\hline South Carolina & 100.0 & 101.4 & 102.1 & 103.4 & 105.0 & 106.7 & 108.4 & 110.0 & 111.7 & 113.3 & 114.9 \\
\hline Tennessee & 100.0 & 101.2 & 101.6 & 102.8 & 104.4 & 106.1 & 107.7 & 109.4 & 111.0 & 112.6 & 114.2 \\
\hline Rest of USA & 100.0 & 101.9 & 104.1 & 106.2 & 108.3 & 110.4 & 112.4 & 114.5 & 116.5 & 118.6 & 120.6 \\
\hline USA & 100.0 & 102.1 & 104.5 & 107.0 & 109.5 & 112.0 & 114.4 & 116.9 & 119.4 & 121.9 & 124.4 \\
\hline
\end{tabular}

Source: Authors' calculations.

${ }^{1}$ Georgia's tax reform is a revenue neutral expansion of the sales tax base and a reduction in the personal income tax rate.

(C) Southern Regional Science Association 2015. 
occurring in Alabama. Georgia's labor supply increases by 11 percent by period 10 of the baseline and by 21 percent over the same period in the simulation of Option A. This is a 90 percent increase in Georgia's labor supply over the 10 periods, which is accompanied by small declines in labor supply in the comparison states and the ROUS. The largest decline in labor supply in percentage terms occurs in Alabama, while South Carolina and Tennessee experience the smallest declines. After 10 periods, Georgia's demand for capital increases by 14.3 percent as a result of adopting Option A. The increase in the demand for capital in Georgia as a result of this reform is accompanied by small declines in the demand for capital in the comparison states and the ROUS. The largest decline in percentage terms occurs in Alabama, while the smallest decline occurs in Florida.

Turning now to the effect of Georgia's tax reform on personal consumption of final goods and services, which is a measure of the welfare effects of reform, we find that consumption increases from 139.9 in period 10 of the baseline simulation to 150.4 in period 10 of the reform. This is an overall increase in consumption of 7.5 percent or a 0.41 percentage point increase in the compound growth rate of consumption. There are small and nearly uniform declines in consumption in percentage terms in the comparison states and the ROUS. ${ }^{17}$

Next, we simulate the effect of Option B, which consists of eliminating Georgia's PIT and recovering the lost revenues by increasing the sales tax rate on the expanded sales tax base. The results of this simulation are reported in Table 5. Option B results in a further 2 percent increase in personal income; a 4.5 percent increase in the consumption of goods; a 4.8 percent increase in labor supply; and a negligible increase in the demand for capital in Georgia. These changes are measured relative to period 10 of Option A. Compared to the baseline simulation, the compound growth rate of personal income over the ten periods is an increase of 0.67 percentage points. After ten periods in the comparison states and the ROUS, there are relatively modest decreases in these four macroeconomic indicators due to Georgia adopting Option B.

Finally, we simulate fundamental state tax reform or Tax Reform Option C. The results of this simulation are reported in Table 6. Interestingly, there is almost no difference in the effect on the four macroeconomic indicators when comparing period 10 of Option $\mathrm{C}$ to period 10 of Option B. More specifically, there is a 1.2 percent decrease in Georgia's personal income; a 0.2 percent increase in the consumption of goods; a 0.5 percent increase in labor supply; and a 0.9 percent decrease in the demand for capital. To maintain revenue neutrality, fundamental state tax reform requires a further increase in the sales tax rate on the expanded sales tax base. Not only are taxes on capital income distortionary, but so are taxes on consumption. For the initial reforms (Options A and B), the tax on capital income are more distortionary than the tax on consumption, particularly in Option A where the replacement tax is an expansion of the sales tax base to include services. Hence, as discussed above, reform options A and B have a salutary effect on

\footnotetext{
${ }^{17}$ One would like to derive aggregate welfare measures as a way of judging the relative merits of the different tax proposals. The typical way of estimating such a measure would be to calculate either the compensated or equivalent variation for each consumer, then summing the variations over all consumers. This is quite straightforward in the context of a static model. In our dynamic regional model with migration, the calculation becomes problematic. The issue is that in our model, labor is sector specific in each region, and migrates from period to period. Thus, the stock of a particular type of labor in a given region changes from period to period. Accordingly, we cannot calculate the present discounted value of the equivalent variation for a particular representative agent (that is, for a type of sectorial labor), since that agent's stock of labor in the home region changes over time. Similarly, if we attempt to calculate period by period equivalent variations, and then sum them over time, we will have a meaningless number since migration makes the representative sectorial agent different in each period.
} 
Table 5: The Effect of Tax Reform Option B on Key Macroeconomic Variables

by State and by Period ${ }^{1}$

\begin{tabular}{|c|c|c|c|c|c|c|c|c|c|c|c|}
\hline \multirow[b]{2}{*}{ State } & \multicolumn{11}{|c|}{ Period } \\
\hline & $\mathbf{0}$ & 1 & 2 & 3 & 4 & 5 & 6 & 7 & 8 & 9 & 10 \\
\hline & \multicolumn{11}{|c|}{ Personal Income } \\
\hline Alabama & 100.0 & 101.1 & 102.9 & 105.5 & 108.4 & 111.4 & 114.6 & 117.8 & 121.1 & 124.5 & 128.0 \\
\hline Florida & 100.0 & 100.9 & 102.3 & 104.7 & 107.3 & 109.9 & 112.5 & 115.1 & 117.7 & 120.3 & 122.9 \\
\hline Georgia & 101.9 & 104.3 & 108.7 & 113.1 & 117.9 & 122.9 & 128.1 & 133.5 & 139.2 & 145.2 & 151.4 \\
\hline North Carolina & 100.0 & 102.5 & 106.1 & 110.4 & 115.1 & 119.9 & 124.9 & 130.1 & 135.5 & 141.1 & 146.9 \\
\hline South Carolina & 100.0 & 100.5 & 101.3 & 102.9 & 104.9 & 106.8 & 108.7 & 110.6 & 112.5 & 114.3 & 116.2 \\
\hline Tennessee & 100.0 & 100.4 & 101.1 & 102.6 & 104.4 & 106.3 & 108.2 & 110.1 & 111.9 & 113.8 & 115.6 \\
\hline Rest of USA & 100.0 & 101.3 & 103.6 & 106.0 & 108.4 & 110.8 & 113.3 & 115.8 & 118.2 & 120.6 & 123.0 \\
\hline \multirow[t]{2}{*}{ USA } & 100.0 & 101.4 & 103.6 & 106.1 & 108.7 & 111.2 & 113.8 & 116.5 & 119.1 & 121.7 & 124.3 \\
\hline & \multicolumn{11}{|c|}{ Consumption of Goods } \\
\hline Alabama & 100.0 & 101.1 & 102.9 & 105.6 & 108.6 & 111.9 & 115.4 & 118.9 & 122.6 & 126.5 & 130.5 \\
\hline Florida & 100.0 & 100.8 & 102.3 & 104.3 & 106.9 & 109.6 & 112.2 & 114.9 & 117.6 & 120.3 & 123.1 \\
\hline Georgia & 105.6 & 108.4 & 112.3 & 116.8 & 121.8 & 127.1 & 132.6 & 138.4 & 144.4 & 150.6 & 157.1 \\
\hline North Carolina & 100.0 & 102.7 & 106.8 & 111.7 & 117.0 & 122.4 & 128.1 & 134.0 & 140.2 & 146.7 & 153.4 \\
\hline South Carolina & 100.0 & 100.5 & 101.2 & 102.4 & 104.2 & 106.1 & 107.9 & 109.7 & 111.5 & 113.3 & 115.2 \\
\hline Tennessee & 100.0 & 100.5 & 101.1 & 102.3 & 104.0 & 105.9 & 107.7 & 109.6 & 111.4 & 113.3 & 115.1 \\
\hline Rest of USA & 100.0 & 101.0 & 103.3 & 105.7 & 108.1 & 110.5 & 113.0 & 115.4 & 117.8 & 120.3 & 122.7 \\
\hline \multirow[t]{2}{*}{ USA } & 100.1 & 101.3 & 103.5 & 106.0 & 108.5 & 111.1 & 113.7 & 116.4 & 119.0 & 121.7 & 124.4 \\
\hline & \multicolumn{11}{|c|}{ Labor Supply } \\
\hline Alabama & 100.0 & 100.2 & 99.7 & 99.8 & 100.3 & 100.9 & 101.7 & 102.5 & 103.4 & 104.2 & 105.1 \\
\hline Florida & 100.0 & 100.3 & 99.7 & 99.6 & 99.8 & 100.1 & 100.4 & 100.7 & 101.0 & 101.3 & 101.5 \\
\hline Georgia & 101.0 & 102.8 & 105.5 & 108.0 & 110.4 & 112.8 & 115.2 & 117.7 & 120.2 & 122.8 & 125.6 \\
\hline North Carolina & 100.0 & 100.3 & 100.2 & 100.6 & 101.4 & 102.3 & 103.4 & 104.6 & 105.9 & 107.3 & 108.8 \\
\hline South Carolina & 100.0 & 100.3 & 99.5 & 99.5 & 99.8 & 100.2 & 100.7 & 101.1 & 101.5 & 101.9 & 102.3 \\
\hline Tennessee & 100.0 & 100.2 & 99.4 & 99.3 & 99.6 & 100.0 & 100.3 & 100.7 & 101.1 & 101.4 & 101.7 \\
\hline Rest of USA & 100.0 & 100.9 & 101.5 & 102.0 & 102.5 & 103.0 & 103.5 & 104.0 & 104.4 & 104.9 & 105.3 \\
\hline \multirow[t]{2}{*}{ USA } & 100.0 & 100.8 & 101.4 & 101.9 & 102.5 & 103.0 & 103.6 & 104.1 & 104.6 & 105.2 & 105.7 \\
\hline & \multicolumn{11}{|c|}{ Demand for Capital } \\
\hline Alabama & 100.0 & 102.4 & 105.1 & 108.5 & 112.2 & 116.1 & 120.5 & 124.9 & 129.5 & 134.3 & 139.2 \\
\hline Florida & 100.0 & 102.6 & 106.0 & 109.9 & 114.0 & 118.0 & 122.1 & 126.3 & 130.5 & 134.6 & 138.8 \\
\hline Georgia & 100.0 & 105.4 & 112.3 & 119.2 & 126.2 & 133.3 & 140.7 & 148.2 & 155.9 & 163.9 & 172.1 \\
\hline North Carolina & 100.0 & 104.9 & 110.6 & 116.8 & 123.3 & 130.1 & 137.1 & 144.3 & 151.8 & 159.7 & 167.8 \\
\hline South Carolina & 100.0 & 101.2 & 102.0 & 103.4 & 105.0 & 106.6 & 108.2 & 109.8 & 111.4 & 112.9 & 114.3 \\
\hline Tennessee & 100.0 & 100.9 & 101.5 & 102.8 & 104.4 & 106.0 & 107.6 & 109.2 & 110.7 & 112.2 & 113.6 \\
\hline Rest of USA & 100.0 & 101.9 & 104.0 & 106.1 & 108.1 & 110.2 & 112.2 & 114.2 & 116.1 & 118.0 & 119.9 \\
\hline USA & 100.0 & 102.1 & 104.5 & 106.9 & 109.4 & 111.8 & 114.2 & 116.6 & 119.0 & 121.5 & 123.8 \\
\hline
\end{tabular}

(C) Southern Regional Science Association 2015. 


\section{Table 6: The Effect of Tax Reform Option C on Key Macroeconomic Variables} by State and by Period ${ }^{1}$

\begin{tabular}{|c|c|c|c|c|c|c|c|c|c|c|c|}
\hline \multirow[b]{2}{*}{ State } & \multicolumn{11}{|c|}{ Period } \\
\hline & $\mathbf{0}$ & 1 & 2 & 3 & 4 & 5 & 6 & 7 & 8 & 9 & 10 \\
\hline & \multicolumn{11}{|c|}{ Personal Income } \\
\hline Alabama & 100.0 & 101.0 & 102.8 & 105.5 & 108.3 & 111.3 & 114.4 & 117.6 & 120.8 & 124.2 & 127.5 \\
\hline Florida & 100.0 & 100.8 & 102.3 & 104.7 & 1073 & 109.8 & 112.4 & 115.0 & 117.6 & 120.2 & 122.8 \\
\hline Georgia & 102.1 & 104.6 & 108.8 & 113.2 & 117.9 & 122.9 & 128.1 & 133.4 & 139.0 & 144.9 & 151.0 \\
\hline North Carolina & 100.0 & 102.4 & 106.0 & 110.3 & 114.9 & 119.7 & 124.6 & 129.7 & 135.0 & 140.6 & 146.3 \\
\hline South Carolina & 100.0 & 100.5 & 101.3 & 103.0 & 104.9 & 106.8 & 108.7 & 110.6 & 112.5 & 114.3 & 116.1 \\
\hline Tennessee & 100.0 & 100.4 & 101.0 & 102.6 & 104.4 & 106.3 & 108.2 & 110.1 & 111.9 & 113.8 & 115.6 \\
\hline Rest of USA & 100.0 & 101.3 & 103.6 & 105.9 & 108.4 & 110.8 & 113.3 & 115.7 & 118.1 & 120.5 & 122.9 \\
\hline \multirow[t]{2}{*}{ USA } & 100.0 & 101.4 & 103.6 & 106.1 & 108.6 & 1112 & 113.8 & 116.4 & 119.0 & 121.6 & 124.2 \\
\hline & \multicolumn{11}{|c|}{ Consumption of Goods } \\
\hline Alabama & 100.0 & 101.1 & 102.9 & 105.6 & 108.6 & 111.9 & 115.3 & 118.9 & 122.6 & 126.4 & 130.4 \\
\hline Florida & 100.0 & 100.8 & 102.3 & 104.3 & 106.9 & 109.6 & 112.2 & 114.9 & 117.6 & 120.3 & 123.0 \\
\hline Georgia & 105.8 & 108.6 & 112.6 & 117.1 & 122.1 & 127.4 & 132.9 & 138.6 & 144.6 & 150.9 & 157.4 \\
\hline North Carolina & 100.0 & 102.7 & 106.8 & 111.7 & 117.0 & 122.4 & 128.1 & 134.0 & 140.2 & 146.6 & 153.4 \\
\hline South Carolina & 100.0 & 100.5 & 101.2 & 102.5 & 104.2 & 106.1 & 107.9 & 109.7 & 111.5 & 113.3 & 115.1 \\
\hline Tennessee & 100.0 & 100.5 & 101.1 & 102.3 & 104.0 & 105.9 & 107.7 & 109.6 & 111.4 & 113.2 & 115.1 \\
\hline Rest of USA & 100.0 & 101.1 & 103.3 & 105.7 & 108.1 & 110.5 & 112.9 & 115.4 & 117.8 & 120.2 & 122.6 \\
\hline \multirow[t]{2}{*}{ USA } & 100.1 & 101.3 & 103.5 & 106.0 & 108.5 & 111.1 & 113.7 & 116.4 & 119.0 & 121.6 & 124.3 \\
\hline & \multicolumn{11}{|c|}{ Labor Supply } \\
\hline Alabama & 100.0 & 100.05 & 99.6 & 99.8 & 100.2 & 100.9 & 101.6 & 102.4 & 103.2 & 104.0 & 104.9 \\
\hline Florida & 100.0 & 100.18 & 9968 & 99.6 & 99.8 & 100.1 & 100.4 & 100.7 & 101.0 & 101.3 & 101.5 \\
\hline Georgia & 101.1 & 102.86 & 105.5 & 107.8 & 110.1 & 112.5 & 114.9 & 117.3 & 119.8 & 122.3 & 125.0 \\
\hline North Carolina & 100.0 & 100.18 & 100.0 & 100.4 & 101.2 & 102.1 & 103.2 & 104.3 & 105.6 & 107.0 & 108.5 \\
\hline South Carolina & 100.0 & 100.15 & 99.5 & 99.6 & 99.9 & 100.3 & 100.8 & 101.2 & 101.6 & 102.0 & 102.4 \\
\hline Tennessee & 100.0 & 100.08 & 99.4 & 99.4 & 99.7 & 100.1 & 100.4 & 100.8 & 101.2 & 101.5 & 101.9 \\
\hline Rest of USA & 100.0 & 100.85 & 101.5 & 102.0 & 102.5 & 103.0 & 103.5 & 104.0 & 104.4 & 104.9 & 105.3 \\
\hline \multirow[t]{2}{*}{ USA } & 100.0 & 100.83 & 101.4 & 101.9 & 102.5 & 103.0 & 103.5 & 104.1 & 104.6 & 105.2 & 105.7 \\
\hline & \multicolumn{11}{|c|}{ Demand for Capital } \\
\hline Alabama & 100.0 & 102.4 & 105.2 & 108.6 & 112.3 & 116.4 & 120.7 & 125.3 & 130.0 & 134.8 & 139.8 \\
\hline Florida & 100.0 & 102.7 & 106.0 & 110.0 & 114.0 & 118.1 & 122.2 & 126.4 & 130.5 & 134.7 & 138.9 \\
\hline Georgia & 100.0 & 105.4 & 112.6 & 119.7 & 126.8 & 134.1 & 141.6 & 149.2 & 157.1 & 165.2 & 173.7 \\
\hline North Carolina & 100.0 & 105.0 & 110.7 & 117.0 & 123.6 & 130.4 & 137.4 & 144.8 & 152.3 & 160.2 & 168.4 \\
\hline South Carolina & 100.0 & 101.2 & 101.9 & 103.3 & 104.9 & 106.5 & 108.1 & 109.7 & 111.3 & 112.8 & 114.3 \\
\hline Tennessee & 100.0 & 101.0 & 101.5 & 102.7 & 104.3 & 105.9 & 107.5 & 109.1 & 110.6 & 112.1 & 113.6 \\
\hline Rest of USA & 100.0 & 101.9 & 104.0 & 106.1 & 108.2 & 110.2 & 112.2 & 114.2 & 116.2 & 118.1 & 120.0 \\
\hline USA & 100.0 & 102.1 & 104.5 & 106.9 & 109.4 & 111.8 & 114.3 & 116.7 & 119.1 & 121.6 & 124.0 \\
\hline
\end{tabular}

(C) Southern Regional Science Association 2015. 
the four macroeconomic indicators of Georgia. Nevertheless, the benefit of a further reduction in the distortionary tax on capital income by fundamental state tax reform relative to Option B is nearly completely offset by the cost of a further increase in the distortionary tax on consumption relative to Option B. It is the net effect of these two distortions moving in opposite directions that accounts for the small increase in personal income from fundamental state tax reform relative to the increase resulting from the adoption of Option B. With only a few exceptions, there are very slight declines in the four macroeconomic indicators for the comparison states and the ROUS in period 10 for Option $\mathrm{C}$ relative to the corresponding period for Option B. However, there are slight increases in the supplies of labor in South Carolina and Tennessee and in the demands for capital in Alabama, Florida, and North Carolina.

Before proceeding with some general observations on the effect of fundamental state tax reform, we examine its effect on economic activity by sector. Table 7 reports the percent change in economic activity by sector and by state due to fundamental state tax reform in period 10 relative to period 10 of the baseline. In Georgia, manufacturing increases by 12.5 percent, trade by 16.9 percent, transportation by 19.2 percent, finance by 14 percent, with much smaller increases in real estate and services. Interestingly, state and local government enjoys the largest growth rate as a result of fundamental tax reform. This result is undoubtedly an artifact of the way in which we model state and local expenditures. Recall that state and local expenditures are assumed to be proportional to a state's value of production; and state and local transfers are assumed to be proportional to a state's total income. Since tax reform increases the value of production and total income in Georgia, there are proportional increases in state and local government spending and transfers, respectively, as well.

The growth of these sectors in Georgia mostly comes at the expense of Alabama and North Carolina, with smaller declines in these sectors for the remaining three states and the ROUS. It is interesting to note that with the single exception of state and local government, there are small declines in the total level of activity in these sectors for the United States as a whole.

Interestingly, fundamental tax reform in Georgia leads to a slight reduction in the demand for capital in the United States as a whole relative to the baseline. In contrast to fundamental national tax reform, which increases capital formation, fundamental state tax reform in a single state has a small negative effect on capital formation for the country as a whole. In this sense, fundamental state tax reform is truly "beggar thy neighbor." ${ }^{\text {" }}$ This observation illustrates the importance of using a dynamic open economy model to simulate state tax reforms. This finding also suggests that tax harmonization among the states, as opposed to a single state independently pursuing tax reform, may be of greater benefit to the U.S. economy as a whole. The effect of tax harmonization among the states merits further research but is beyond the scope of the current paper.

Thus far, we can summarize our main findings as follows. Tax Reform Option A results in a 0.51 percentage point increase in the compound growth rate of personal income and a 0.41 percentage point increase in consumption relative to the baseline after 10 periods. Option B, relative to the baseline, increases the compound growth rate of personal income by 0.67

\footnotetext{
${ }^{18}$ Fundamental national tax reform may have important interregional effects as well. To the best of our knowledge, no one has used a regional model to simulate the effect of fundamental national tax reform; thus the interregional effects of such a reform is unknown. This would be an interesting topic for future research.
}

(C) Southern Regional Science Association 2015. 
Table 7: Percent Change in Activity by Sector in Period 10 Due to Tax Reform Option C Relative to the Baseline ${ }^{1}$

\begin{tabular}{|c|c|c|c|c|c|c|c|}
\hline State & Manufacturing & Trade & Transportation & Finance & Real Estate & Services & $\begin{array}{c}\text { State and Local } \\
\text { Government }\end{array}$ \\
\hline Alabama & -8.1 & -3.4 & -5.5 & -1.3 & -1.5 & -2.0 & -1.0 \\
\hline Florida & -3.0 & -2.1 & -2.5 & -1.2 & 0.2 & -2.2 & -1.0 \\
\hline Georgia & 12.5 & 16.9 & 19.2 & 14.0 & 3.2 & 3.8 & 21.0 \\
\hline North Carolina & -4.4 & -4.7 & -5.7 & -2.7 & -0.1 & -2.6 & -0.7 \\
\hline South Carolina & -2.7 & -1.8 & -2.0 & -1.0 & -0.3 & -1.7 & -0.7 \\
\hline Tennessee & -3.0 & -1.8 & -2.3 & -1.0 & -0.3 & -1.8 & -0.8 \\
\hline Rest of U.S.A. & -3.4 & -1.7 & -2.2 & -0.7 & -0.5 & -1.1 & -0.5 \\
\hline United States & -3.0 & -1.1 & -1.4 & -0.4 & -0.3 & -1.1 & 0.1 \\
\hline
\end{tabular}

Source: Authors' calculations.

${ }^{1}$ Georgia's Tax Reform Option $\mathrm{C}$ is the elimination of the corporate and personal income taxes and a revenue neutral increase in the state sales tax rate on a broadened sales tax base. 
percentage points and increases consumption by 0.64 percentage points. Finally, fundamental state tax reform, i.e., Option $\mathrm{C}$, increases the compound growth rate of personal income and consumption relative to the baseline by 0.62 and 0.64 percentage points, respectively. Relative to the baseline, the increases in compound growth rates of personal income and consumption as a result of these three tax reform options range between 12 and 20 percent over the ten-year period.

By decomposing fundamental state tax reform into three incremental reforms, we find that there are diminishing returns to decreasing the distortionary tax on capital income. This is due to the need to increase the distortionary tax on consumption in order to maintain revenue neutrality. In fact, the net effect of these two opposing effects is approximately zero when comparing the index of personal income in period 10 of Option C (151) to that of Option B (151.4).

In addition to comparing growth rates in levels, it would be meaningful to consider the effects of tax reform in per capita terms. While the growth rates of income and consumption increase in Georgia as a result of these reforms, the growth rate of labor supply in Georgia also increases. There are two reasons for the increases in Georgia's labor supply: labor supply increases as a result of migration of labor from other states to Georgia and as a result of increases in labor supply among the original residents of Georgia. Both effects are due to the increases in real wages that result from increased capital formation in Georgia due to increases in the aftertax return to capital relative to the after-tax returns available in the comparison states and the ROUS. Given that there are two sources for the increase in labor supply, it is not possible to make precise estimates of the growth rate changes in per capita terms resulting from tax reform. With this important caveat in mind, income per unit of labor - the ratio of personal income and labor supply-increases by 25.4 percent over the 10 periods in the baseline. In contrast, this ratio increases by only 19.8 percent in the case of fundamental tax reform (Option C). Thus, fundamental tax reform actually decreases income per unit of labor by 3.7 percent relative to the baseline. On the other hand, there is virtually no change in consumption per unit of labor-the ratio of final consumption and labor supply - in period 10 of Option $\mathrm{C}$ (1.259) relative to the corresponding period of the baseline (1.254). Just to be clear, one must be cautious in concluding that there are no benefits to fundamental state tax reform in per capita terms because we do not have precise estimates of the growth in Georgia's population as a result of tax reform.

As with any simulation exercise, one should assess the credibility of the findings. In other words, would the fundamental state tax reform modeled here, if actually implemented, increase the growth rate of personal income in Georgia by 0.6 percentage points as reported here? Since there are no confidence intervals for this estimate, we cannot specify the probability that the estimate would fall within a certain range. Using different values for the parameters developed through the calibration process would produce different results, but we do not know if such results are closer to the unknown true values. Nor will such an exercise yield confidence intervals. Nonetheless, our expectation is that our estimate of a 0.6 percentage point increase in the growth rate of personal income due to fundamental tax reform may be on the high side.

First, as noted above, the baseline growth rate in income per capita is greater than Georgia's recent historical experience. This may result in an upward bias in our estimate of the long-run growth rate in personal income due to fundamental tax reform. Second, the sales tax that we are able to model does not account for sales taxes on specific business inputs, which is 
the actual practice in Georgia. If the model accounted for sales taxes on specific business inputs, the effects of the sorts of tax reforms modeled here would likely be smaller because the sales tax would be more distortionary than the one we are able to model. Third, Altig et al. (2001) obtain effects that are similar in size to ours, but they model a much larger reduction in the tax burden on capital income than we do. Again, this suggests that our estimate may be on the high side. On the other hand, the model results of Altig et al. and our model are not directly comparable because they model a closed economy while ours is an open economy model. In particular, the capital flows generated by our open economy formulation would naturally lead to larger changes than would a closed economy specification. As previously discussed, we believe that it is particularly important to model state tax reform as an open economy because the interregional mobility of factors and the interregional trade in goods and services in a highly integrated common market, like the U.S. economy, are much greater than the international mobility of factors and international trade in goods. Fourth, we do not consider the possible reaction of other states to Georgia's tax reform. If other states were to follow Georgia's lead and adopt similar tax reforms, Georgia's growth rate would likely be smaller because the factor inflows to Georgia due to tax reform would be smaller. In short, we do believe that the tax reforms modeled here will increase Georgia's long-run growth rate in personal income, but the effect may be somewhat smaller than the reported estimate of 0.6 percentage points in the case of fundamental tax reform.

\section{CONCLUSION}

We use an innovative multistate, dynamic, open economy, general equilibrium model to gauge the economic impact of three revenue neutral tax reforms in Georgia. These reforms would decrease the CIT and PIT rates eventually to zero, broaden the sales tax base to include services, and increase the sales tax rate. The dynamic and multistate specification of our model is an advance over previous simulation models used to evaluate state tax reforms in the U.S. context. These features of our model are particularly important in simulating the effect of tax reforms that reduce the after-tax rate of return to capital. Unlike previous models, we use a nonArmington approach in which goods traded between states are viewed as being identical and thus perfect substitutes in production and consumption. This approach has a number of advantages over Armington models. First, it allows us to account for changes in relative wages by sector in a state due to fiscal instruments. This approach also reduces the dimensionality of the model thus greatly reducing the computational burden of solving for the equilibrium. In our model, capital is perfectly mobile across states and industries, while labor is both state and industry specific in the short run. The model is solved backwards to yield sector and state wage rates, while there is a single price for capital, and the prices for final goods are set at the national level.

As expected, we find that fundamental state tax reform has an economically substantial positive effect on the growth rates of personal income and of consumption. The benefits to Georgia from tax reform come at the expense of its comparison states and the ROUS. Essentially, Georgia attracts capital and labor from its neighbors. However, the aggregate increases in economic activity as a result of fundamental tax reform in Georgia may not be as dramatic as some advocates of such reforms imagine.

\section{REFERENCES}

Aaron, Henry J. and William G. Gale. (1996) Economic Effects of Fundamental Tax Reform. The Brookings Institution: Washington, DC. 
Altig, David, Alan J. Auerbach, Laurence J. Kotlikoff, Kent A. Smetters, and Jan Walliser. (2001) "Simulating Fundamental Tax Reform in the United States," American Economic Review, 91, 574-595.

Armington, Paul. (1969) "A Theory of Demand for Products Distinguished by Place of Production," IMF Staff Papers 16, 159-178.

Auerbach, Alan J. (1996) "Tax Reform, Capital Allocation, Efficiency, and Growth," in Henry J. Aaron and William G. Gale, eds., Economic Effects of Fundamental Tax Reform. The Brookings Institution: Washington, DC, pp. 29-73.

Auerbach, Alan J. and Laurence J. Kotlikoff. (1987) Dynamic Fiscal Policy. Cambridge University Press: Cambridge, MA.

Ballard, Charles L. (2002) "International Aspects of Fundamental Tax Reform," in George R. Zodrow and Peter Mieszkowski, eds., United States Tax Reform in the 21st Century. Cambridge University Press: Cambridge, MA, pp. 109-139.

Ballard, Charles L., John B. Shoven, and John Whalley. (1985) "General Equilibrium Computations of the Marginal Welfare Costs of Taxation in the United States," American Economic Review, 75, 128-138.

Baum, Donald N. (1998) "Economic Effects of Eliminating the Sales Tax Exemption for Food: An Applied General Equilibrium Analysis," Journal of Economics (MVEA), 24, 125148.

Berck, Peter, Elise Golan, and Bruce Smith. (1997) "State Tax Policy, Labor, and Tax Revenue Feedback Effects," Industrial Relations, 36, 339-418.

Boortz, Neal and John Linder. (2005) The Fair Tax Book. HarperCollins: New York. . (2008) Fair Tax: The Truth: Answering the Critics. HarperCollins: New York.

Bourdeaux, Carolyn. (2010) “A Review of State Tax Reform Efforts," Fiscal Research Center Report Number 216, Andrew Young School of Policy Studies, Georgia State University, Atlanta, GA.

Bradford, David F. (2003) "The X Tax in the World Economy," CEPS Working Paper No. 93. Center for Philanthropy Studies, University of Basel.

Cutler, Harvey and Irina Strelnikova. (2004) "The Impact of the U.S. Sales Tax Rate on City Size and Economic Activity: A CGE Approach," Urban Studies, 41, 875-885.

Diamond, John W. and George R. Zodrow. (2008) "Consumption Tax Reform: Changes in Business Equity and Housing Prices," in John W. Diamond and George R. Zodrow, eds., Fundamental Tax Reform: Issues, Choices and Implications. MIT Press: Cambridge, MA, pp. 227-280.

Diamond, Peter A. and James A. Mirrlees. (1971) "Optimal Taxation and Public Production I: Production Efficiency," American Economic Review, 61, 8-27.

Dixon, Peter B., Brian R. Parmenter, John Sutton, and D.P. Vincent. (1982) ORANI, a Multisectoral Model of the Australian Economy. North-Holland (Elsevier): Amsterdam.

(C) Southern Regional Science Association 2015. 
Dixon, Peter B., Maureen T. Rimmer, and Glyn Wittmer. (2012) "USAGE-R51, A State-Level Multi-Regional CGE Model of the U.S. Economy," GTAP Conference Paper, Purdue University.

Edmiston, Kelly D. (2002) "Strategic Apportionment of the State Corporate Income Tax: An Applied General Equilibrium Analysis," National Tax Journal, 55, 239-262.

Faulk, Dagney, Nalitra Thaiprasert, and Michael Hicks. (2010) "The Economic Effects of Replacing the Property Tax with a Sales or Income Tax: A Computable General Equilibrium Approach," Department of Economics Working Paper Number 201008, Ball State University.

Feltenstein, Andrew. (1986) “An Intertemporal General Equilibrium Analysis of Financial Crowding Out: A Policy Model and an Application to Australia," Journal of Public Economics, 31, 79-104.

. (1997) "An Analysis of the Implications for the Gold Mining Industry of Alternative Tax Policies: A Regional Disaggregated Model for Australia," Economic Record, 73, 305314.

Feltenstein, Andrew and Florenz Plassmann. (2008) "The Welfare Analysis of a Free Trade Zone: Intermediate Goods and the Asian Tigers," World Economy, 31, 905-924.

Feltenstein, Andrew and Maral Shamloo. (2013) "Tax Reform, the Informal Economy, and Bank Financing of Capital Formation," International Tax and Public Finance, 20, 1-28.

Fullerton, Don and Diane Lim Rogers. (1993) Who Bears the Lifetime Tax Burden? The Brookings Institution: Washington, DC.

Giesecke, James A. (2003) "Targeting Regional Output with State Government Fiscal Instruments: A Dynamic Multi-Regional CGE Analysis," Australian Economic Papers, $42,214-233$.

Giesecke, James A. and John R. Madden. (2013) "Regional Computable General Equilibrium Modeling," in Peter B. Dixon and Dale Jorgenson, eds. Handbook of Computable General Equilibrium Modeling, Vol. 1A. Elsevier: Amsterdam, pp. 379-475.

Hall, Robert E. and Alvin Rabushka. (2007) The Flat Tax, updated edition. Stanford University Press: Palo Alto.

Hamilton, Billy. (2012) “Adios, Income Tax,” State Tax Notes, 63, 963-967.

Hirte, Georg. (1998) "Welfare Effects of Regional Income Taxes: Results of an Interregional CGE Analysis for Germany," Annals of Regional Science, 32, 201-219.

IMPLAN. (2009) State Totals for Alabama, Florida, Georgia, North Carolina, South Carolina, Tennessee, and the USA. IMPLAN Group LLC. Available at: https://implan.com.

Julia-Wise, Roxana, Stephen C. Cooke, and David Holland. (2002) "A Computable General Equilibrium Analysis of a Property Tax Limitation Initiative in Idaho," Land Economics, $78,207-227$.

Mendoza, Enrique G. and Linda L. Tesar. (1998) "The International Ramifications of Tax Reforms: Supply-Side Economics in a Global Economy," American Economic Review, $88,226-245$.

(C) Southern Regional Science Association 2015. 
Merrill, O. H. (1971) "Applications and Extensions of an Algorithm that Computes Fixed Points of Certain Non-Empty Convex Upper Semi-Continuous Point to Set Mappings," unpublished doctoral dissertation, Department of Industrial Engineering, University of Michigan.

Morgan, William, John Mutti, and Mark Partridge. (1989) "A Regional General Equilibrium Model of the United States: Tax Effects on Factor Movements and Regional Production," Review of Economics and Statistics, 71, 626-635.

Neubig, Thomas S., Robert J. Cline, William F. Fox, and Andrew Phillips. (2004) Total State and Local Business Taxes: A 50-State Study of the Taxes Paid by Business in FY 2003. Ernst \& Young LLP.

Pechman, Joseph A. (1980) What Should Be Taxed: Income or Expenditure? The Brookings Institution: Washington, DC.

Pereira, Antonio, and John Shoven. (1988) "A Survey of Dynamic Computational General Equilibrium Models for Tax Policy Evaluation," Journal of Policy Modeling, 10, 401436.

Plassmann, Florenz. (2005) "The Advantage of Avoiding the Armington Assumption in MultiRegion Models," Regional Science and Urban Economics, 35, 777-794.

Randolph, William C. (2006) "International Burdens of the Corporate Income Tax," CBO Working Paper 2006-09.

Rider, Mark. (2006) "The Effect of High State Personal Income Tax Rates on Individual and Firm Behavior-A Review of the Evidence," International Studies Program Working Paper Number 06-15, Andrew Young School of Policy Studies, Georgia State University, April.

Ring, Raymond J. Jr. (1999) "Properties of Consumers' and Producers' Goods in the General Sales Tax," National Tax Journal, 52, 167-179.

Tideman, Nicolaus, Ebere Akobundu, Andrew Johns, and Prapaiporn Wutticharoen. (2002) "The Avoidable Excess Burden of Broad-Based U.S. Taxes," Public Finance Review, 30, 416441.

Turner, Karen, Soo Jun Ha, Geoffrey J.D. Hewings, Peter G. McGregor, and Kim K. Swales. (2012) "Econometric Estimation of Armington Import Elasticities for a Regional CGE Model of the Illinois Economy," Economic Systems Research, 24, 1-19.

Waters, Edward C., David W. Holland, and Bruce Weber. (1997) "Economic Impacts of a Property Tax Limitation: A Computable General Equilibrium Analysis of Oregon's Measure 5," Land Economics, 73, 72-89.

(C) Southern Regional Science Association 2015. 


\section{APPENDIX A. THE NON-ARMINGTON COMPUTATIONAL METHOD}

We illustrate our non-Armington methodology for the simplest case of a static model. The same approach carries over to multi-period models.

Suppose that there is one big region (for example the U.S. or the rest of the world) and K small regions, $\mathrm{k}=1, \ldots, \mathrm{K}$ (for example, Georgia, Alabama, ...). Each region produces intermediate and final goods through an input-output matrix, denoted $\mathrm{A}_{\mathrm{B}}$ for the big region and $\mathrm{A}_{1}, \ldots, \mathrm{A}_{\mathrm{K}}$ for the small regions. Each matrix $A_{i}$ is $\mathrm{N}$ x $\mathrm{N}$ dimensional and each matrix produces exactly the same goods. All intermediate and final goods are perfect substitutes. For each region, there are $\mathrm{N}+1$ factors of production. These are $\mathrm{N}$ sector specific labor types and one capital type. Labor is sector and region specific and capital is perfectly mobile across all regions and sectors.

Consider the big region. Call off a random set of factor prices, $P_{K}, P_{L 1}^{B}, \ldots, P_{L N}^{B}$ for capital and sector labor. Sector $j$ then cost minimizes to produce value added, $V A_{j}\left(P_{K}, P_{L j}^{B}\right)$. Value added is used to produce output via an input-output matrix, $A$, given by:

$$
A=\left[\begin{array}{ccc}
a_{11} & \ldots & a_{1 N} \\
\vdots & \vdots & \vdots \\
a_{N 1} & \ldots & a_{N 1}
\end{array}\right]
$$

Here $a_{i j}$ represents the inputs of intermediate good $i$ needed to produce one unit of good $j$. Sector $j$ selects the relative shares of capital and labor so as to minimize costs per unit of value added. Note that we are still in the big region, we have just left out superscripts. Let:

$$
V A\left(P_{K}, P_{L}\right)=\left[V A_{1}\left(P_{K}, P_{L 1}^{B}\right), \ldots, V A_{N}\left(P_{K}, P_{L N}^{B}\right)\right]
$$

be the vector of cost minimizing value added for the given factor prices.

For zero profits in each sector we must have:

$$
P-P * A-V A\left(P_{K}, P_{L}^{B}\right)=0
$$

where $P$ denotes the vector of sectorial output prices. We thus have:

$$
P=V A\left(P_{K}, P_{L}^{B}\right) *[I-A]^{-1} .
$$

We now have a complete set of prices for all factors, as well as intermediate and final goods, for the big region. Since all goods are traded and the other regions are small, they must be price takers and hence face output prices set in the large region. Thus, sector $j$ in region $k$ faces output price $P_{j}$. Hence, as above we must have:

$$
V A\left(P_{K}, P_{L j}^{k}\right)=P_{j}-P * A_{k} .
$$

Here, $V A\left(P_{K}, P_{L j}^{k}\right)$ is the cost minimizing functional form for value added in sector $j$ of region $k$. Hence, we have one equation and one unknown, $P_{L j}^{k}$, and so we can solve for the sector specific wage rate in each of the small regions.

We now have all the prices that consumers face. Let $U_{j}^{k}(x)$ denote the utility function of a representative consumer who works in sector $j$ of region $k$. Also $x=\left(x_{1}, \ldots, x_{N}\right)$ denotes consumption of each of the $N$ goods that are produced by the input - output matrices. The consumer's maximization problem becomes:

$$
\operatorname{Max} U_{j}^{k}(X) \text { subject to } P * X \leq I(p)=P_{K} W_{K}+P_{L j}^{k} W_{L j}^{k} \text {. }
$$

(C) Southern Regional Science Association 2015. 
Let $\tilde{X}^{*}(P)$ denote aggregate consumption, summed over all consumers, at prices $P$. Let $y_{K j}^{k}, y_{L j}^{k}$ be the cost minimizing inputs of capital and labor, per unit of gross output, in sector $j$ of region $k$. Let $L_{j}^{k}$ be the total supply of sector $j$ type labor in region $k$. Then the sector can produce a total of $L_{j}^{k} / y_{L j}^{k}$ units of $\operatorname{good} j$.

If we then sum over all sectors and all small regions, the total supply of $\operatorname{good} j$ is:

$$
S_{j}(P)=\sum_{k=1}^{n} \frac{L_{j}^{k}}{y_{L j}^{k}}
$$

That is, each sector's supply is constrained by its stock of sector and region specific labor. Then excess demand for good $j$, after production from the small regions, is:

$$
\tilde{X}_{j}^{*}(P)-S_{j}(P) .
$$

This is demand that still needs to be filled after all small regions operate each sector at full employment. Define $D_{j}(P)$ as demand that must be filled by the big region. So:

$$
\begin{gathered}
D_{j}(P)=\tilde{X}_{j}^{*}(P)-S_{j}(P) \text { if } \tilde{X}_{j}^{*}(P)-S_{j}(P)>0 \\
D_{j}(P)=0 \text { if } \tilde{X}_{j}^{*}(P)-S_{j}(P)<0
\end{gathered}
$$

We then solve for the vector of the level of output, $z$, of each sector of the large sector IO matrix as:

$$
z-A_{B} * z=D(P)
$$

Thus, $z=\left[I-A_{B}\right]^{-1} D(P)$.

Let $y_{K j}, y_{L j}$ be the cost minimizing inputs of capital and labor, per unit of gross output, in the big region. Total inputs of capital and labor of type $\mathrm{j}$ are:

$$
Y_{K}=\sum_{j=1}^{N} z_{j} * y_{K j}(P), Y_{L j}=z_{j} * y_{L j}(P) .
$$

Suppose that $Y_{K}^{S}(P)$ is the total inputs of capital by the small regions when operating at their labor constraints. Then the stock of capital left for production by the big region is:

$$
\widetilde{W}_{K} \equiv W_{K}-Y_{K}^{S}(P) .
$$

Hence excess demand for capital is:

$$
Y_{K}-\widetilde{W}_{K}
$$

while excess demand for each of the labor categories is:

$$
Y_{L j}-W_{L j} .
$$

We use a fixed point algorithm based upon Merrill (1971) to then search for prices for capital and the $n$ labor categories in the big region so as to make excess demand $=0$ for the $n+1$ factor prices. Thus, the dimension of the solution space will be equal to the number of labor categories in the big region plus 1, representing capital. The wage rates in each sector of 
each of the small regions have been derived from the output prices determined in the big region, the price of mobile capital, and the zero profit conditions for each sectors production function.

Several things should be noted about our solution algorithm. First, it is completely independent of the non-Armington specification of this particular model. Thus, we can use it to solve any standard general equilibrium model. This particular model is simply a special case that we have solved using Merrill's algorithm. As an example of a recent Armington based model that is solved using Merrill, see, for example, Feltenstein and Shamloo (2013), which is quite complex with many sectors and a dynamic structure. Merrill's homotopy method is very fast, especially current versions, and should not be compared with the original fixed point algorithm of Scarf. It also has the advantage, as compared to certain Newton based algorithms, of not being dependent upon an initial guess of a price vector. Rather, it converges from any starting point.

\section{APPENDIX B. A TWO-PERIOD AUSTRALIAN EXAMPLE}

To illustrate the issues with evaluating the "goodness of fit" of a dynamic approximation, we provide below an example of a two-period model of the Australian economy. As we see, there is a reasonable, but not an exact, approximation of the historical macroeconomic aggregates.

\begin{tabular}{|c|c|c|c|c|}
\hline \multirow{3}{*}{ Macroeconomic Indicator } & $\underline{\text { Simulated }}$ & $\underline{\text { Actual }}$ & $\underline{\text { Simulated }}$ & $\underline{\text { Actual }}$ \\
\hline & \multicolumn{2}{|c|}{ (in billions of $\mathrm{A} \$$ ) } & \multicolumn{2}{|c|}{ (in percent of GDP) } \\
\hline & \multicolumn{3}{|c|}{1981} & 1981 \\
\hline $\mathrm{GDP}^{2}$ & 130.8 & 130.8 & 100.0 & 100.0 \\
\hline Tax revenues & 43.0 & 45.2 & 32.8 & 34.6 \\
\hline Government expenditure & 48.0 & 49.8 & 36.7 & 38.0 \\
\hline Budget surplus (deficit) & -5.0 & -4.6 & -3.9 & -3.5 \\
\hline Gross private investment & 20.8 & 21.7 & 15.9 & 16.6 \\
\hline Exports of goods & 20.0 & 18.7 & 15.3 & 14.3 \\
\hline Imports of goods & 22.8 & 19.2 & 17.4 & 14.7 \\
\hline \multirow[t]{2}{*}{ Trade balance } & -2.8 & -0.5 & -2.1 & -0.4 \\
\hline & \multicolumn{3}{|c|}{1982} & 1982 \\
\hline GDP & 149.8 & 147.9 & 100.0 & 100.0 \\
\hline Tax revenues & 50.9 & 52.6 & 34.0 & 35.6 \\
\hline Government expenditure & 57.0 & 57.4 & 38.1 & 38.8 \\
\hline Budget surplus (deficit) & -6.1 & -4.8 & -4.1 & -3.2 \\
\hline Gross private investment & 21.4 & 26.9 & 14.3 & 18.2 \\
\hline Exports of goods & 18.7 & 19.1 & 12.5 & 12.9 \\
\hline Imports of goods & 25.9 & 22.4 & 17.3 & 15.1 \\
\hline Trade balance & -7.2 & -3.3 & -4.8 & -2.2 \\
\hline
\end{tabular}

(C) Southern Regional Science Association 2015. 